\title{
Herbicides in the Soil Environment: Linkage Between Bioavailability and Microbial Ecology
}

\author{
M. Celina Zabaloy ${ }^{1}$, Graciela P. Zanini ${ }^{1}$, Virginia Bianchinotti ${ }^{1}$, \\ Marisa A. Gomez ${ }^{1}$ and Jay L. Garland ${ }^{2}$ \\ 1 Universidad Nacional del Sur \\ ${ }^{2}$ Dynamac Corp. \\ ${ }^{1}$ Argentina \\ ${ }^{2}$ United States
}

\section{Introduction}

Modern agriculture relies heavily on herbicides for the control of weeds in crops and pastures to maximize yields and economical benefits to sustain an increasing world population. The introduction of herbicide-resistant traits in several crops, such as glyphosate-resistant (GR) soybean, maize and canola, has further increased herbicide consumption worldwide (Cerdeira \& Duke, 2006). United States consumed roughly 200 million $\mathrm{kg}$ in 2001, with glyphosate representing $20 \%$ of the total. Glyphosate is, undoubtedly, the most used herbicide worldwide (Woodburn, 2000). In Argentina, where GR soybean accounts for almost $90 \%$ of planted soybean, it was estimated that 160 million 1 of glyphosate were used with this crop in 2004, representing $37 \%$ of the total herbicide consumed in agriculture (Altieri \& Pengue, 2006; Pengue, 2004).

The environmental fate of herbicides is a matter of recent concern given that only a small fraction of the chemicals reach the target organisms (Pimentel, 1995), leading to potential impacts of residual herbicides in soil and water have on human, animal and crop health. Bunce (1993) wrote in 1993 "It is useful to keep in mind the concept that a pollutant is a substance in the wrong place, at the wrong time, or in the wrong amount". While herbicides are very important to agriculture, under certain circumstances they may act as pollutants that can deteriorate soils, ground waters and surface waters. While most herbicides are not intentionally applied onto soil, they can enter the soil environment from 1) direct interception of spray by the soil surface during early season or post-harvest applications, 2) runoff of the herbicide from vegetation and 3) leaching from dead plant material. The herbicide concentration may vary from a few $\mu \mathrm{g}$ to $\mathrm{mg}$ per $\mathrm{kg}$ soil, as most of the applied chemical is retained within the top $5 \mathrm{~cm}$ of soil. This chapter will present aspects of the behavior of herbicides in soils, focusing on soil retention and microbial degradation as main factors controlling persistence. The potential impact of herbicides on non-target soil microbes, including their processes and interactions, will be also discussed.

Adsorption to soil is of critical importance for the regulation of herbicide persistence and mobility throughout the environment because sorption processes control the amount of 
herbicide present in the soil solution. These processes are dependent on several factors related to soil characteristics such as mineral composition, organic matter content, soil solution chemistry, and chemical characteristics of the herbicide. Soil-bound herbicide or residues are temporarily inactivated, which prevents harmful effects on soil biota but also makes them less bioavailable for microbial degradation because most microbes may not be able to utilize herbicides in the sorbed state (Ainsworth et al., 1993). Soil biochemical and biological processes are critical for ecosystems functioning, as microbes have key roles in organic matter transformations, nutrient cycling and degradation of organic pollutants, including pesticides (Beck et al., 2005). Biological degradation mediated by microbial enzymes is the main route for pesticides detoxification in soils (van Eerd et al., 2003). Most isolated herbicide-degrading microorganisms belong to bacterial species, but fungi are also well-known for their capacity to degrade complex substrates, and may be more important than present isolation approaches have suggested (Smith \& Collins, 2007). Differential toxicity of herbicides to soil microorganisms may alter community structure, including potential increases in plant or animal pathogens. Herbicides may also cause changes in microbial community function and concomitant impacts on soil health and ecosystem processes. Even though functions may appear unaltered, due to species redundancy in soil, the extinction of resistant species may compromise the continuity of such processes.

The enormous variety of herbicides commercially available today makes it impossible to review all of them. Thus, this work will focus on some of the herbicides most used in the (semiarid) Pampa region of Argentina and worldwide (i.e., glyphosate, 2,4 dichlorophenoxyacetic acid, metsulfuron-methyl), based on our own research data.

\section{Factors influencing the fate of herbicides in soil}

\subsection{Physicochemical interactions with soil}

Soil is one of the main regulators of herbicide mobility in the environment. Many chemical and biological processes that determine the retention or transport of herbicides take place on the soil surface. These processes include adsorption phenomena, chemical degradation, and biological degradation. While all these processes are interrelated, occurring in parallel (Cheng, 1990), it is important to first understand adsorption since it regulates the bioavailability of herbicides in the environment, i.e. the ability to be used by microorganisms and thus be biodegraded (Laor et al., 1996; Boesten, 1993; Martins \& Mermoud, 1998). Adsorption determines the quantity of herbicide that is retained on the soil surface and therefore is one of the primary processes that affect the transport of these compounds in soils. Thus to relate bioavailability and microbial ecology it is helpful to understand this primary process. Soils are complex assemblies of solids, liquids, and gases. A typical mineral soil contains $50 \%$ solid material ( $45 \%$ mineral and $5 \%$ organic matter) and $50 \%$ pore space. The mineral particles in the soil are distributed into three sizes: sand, silt, and clay. Between the solid components of soil is space forming pores that plays a major role in movement of water, solutes and air. The adsorption processes depend fundamentally on the composition and properties of the solid component as well as the physicochemical characteristics of the herbicide. The solid component is formed mainly by primary and secondary minerals and by organic matter. These materials provide the specific sites for herbicide adsorption. Their properties and behavior have been treated extensively (Dixon \& Weed, 1990; Greenland \& Hayes, 1978). 
Important characteristics of herbicides include: structure of the compound (including functional groups), water solubility, vapor pressure, octanol-water partitioning constant (Kow), and acidity. Table 1 shows the structures and some physicochemical properties of glyphosate, 2,4-D and metsulfuron-methyl.

The distribution of an herbicide in the soil depends on partitioning between the soil solution and the solid phase (Figure 1). The chemical is partitioned between the soil solution and the solid phase. The proper term for this process is adsorption equilibrium, which can be written to describe the interaction between any herbicide and any soil component as follows:

$$
\mathrm{S}+\mathrm{H}(\mathrm{aq}) \rightleftharpoons \mathrm{SH}
$$

Where $\mathrm{S}$ represents a surface site of soil, $\mathrm{H}(\mathrm{aq})$ the herbicide in soil solution and $\mathrm{SH}$ the herbicide attached to the surface site. Surface sites where the herbicide can be adsorbed are numerous and varied in soils. These sites are provided by soil minerals (clays, Fe and Mn oxides, etc) as well as by organic matter. Equation (1) gives an idea of the general process involving adsorption, but it does not specify the mechanism by which it occurs, which are varied in the complex soil system (formation of surface complexes, electrostatic interactions, hydrophobic interactions, ion exchange, etc.).

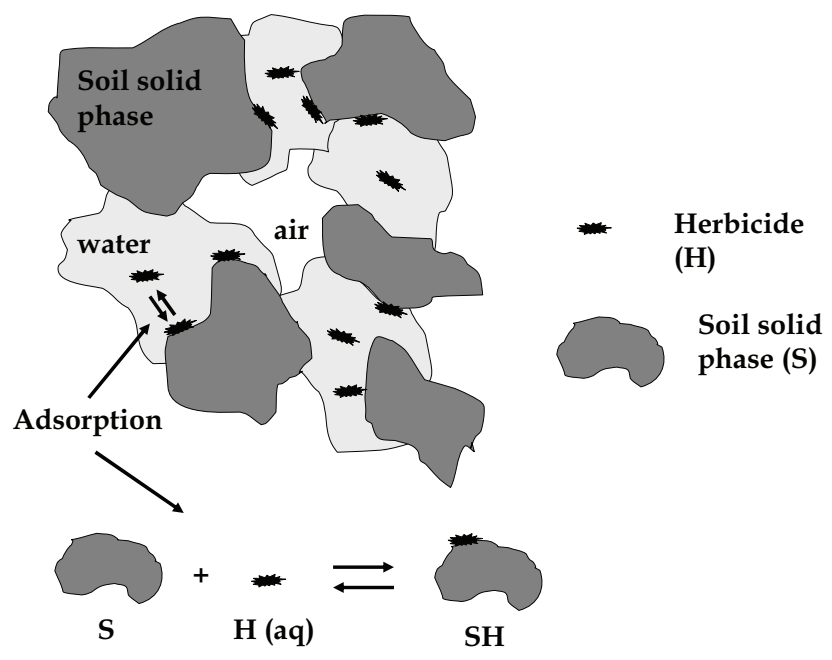

Fig. 1. Distribution of an herbicide in soil

Defining the bioavailability of an herbicide requires an understanding of the strength of its 1) interaction with a particular soil and 2) concentration of herbicide in the soil solution. This can be known by using adsorption isotherms. An adsorption isotherm shows the relationship between the herbicides concentration in the soil solution $(\mathrm{C}$, correspond to $\mathrm{H}(\mathrm{aq})$ in Equation (1) and the amount adsorbed (q, correspond to $\mathrm{SH}$ in Equation (1)) at constant temperature and after equilibrium was reached (Stumm, 1992). As an example, Figure 2 shows adsorption isotherms of the herbicide metsulfuron methyl (MM) on different soils of the semiarid pampean region of Argentina (Zanini et al., 2009). Although isotherms with 30 different soils were measured in that study, the figure presents the results for three 
selected soils. These soils are characterized by having rather similar specific surface areas (SSA) and clay contents (\% clay), but rather different total organic carbon (TOC) content. The physical and chemical characteristics of the 30 soils are shown in Table 2.

\begin{tabular}{|c|c|c|c|c|c|}
\hline Herbicide & $\begin{array}{l}\text { Chemical } \\
\text { Structure }\end{array}$ & $\mathrm{pKa}$ & \begin{tabular}{|c|} 
Water \\
Solubility
\end{tabular} & $\begin{array}{l}\text { Log } \\
\mathrm{K}_{\mathrm{ow}}\end{array}$ & $\begin{array}{l}\text { Vapour } \\
\text { Pressure } \\
(\mathrm{Pa})\end{array}$ \\
\hline $\begin{array}{l}\text { Metsulfuron } \\
\text { Methyl (MM) }\end{array}$ & 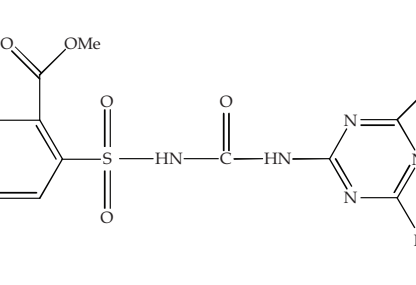 & 3.3 & $\begin{array}{c}548 \mathrm{mg} \\
\mathrm{L}^{-1}(\mathrm{pH} 5) \\
2.79 \mathrm{~g} \\
\mathrm{~L}^{-1}(\mathrm{pH} 7) \\
213 \mathrm{~g} \\
\mathrm{~L}^{-1}(\mathrm{pH} 9 \\
\left.20^{\circ} \mathrm{C}\right)\end{array}$ & $\begin{array}{c}1.8 \\
(\mathrm{pH} 5) \\
0.018 \\
(\mathrm{pH} \mathrm{7}) \\
0.0002 \\
(\mathrm{pH} 9, \\
\left.25^{\circ} \mathrm{C}\right)\end{array}$ & $1.1 \times 10^{-10}$ \\
\hline $\begin{array}{l}\text { Glyphosate } \\
\text { (Gly) }\end{array}$ & $\stackrel{\mathrm{OH}}{\|}_{\left.\right|_{\mathrm{OH}} ^{\mathrm{P}}}^{\mathrm{O}}$ & $\begin{array}{c}2.3 \\
5.3 \\
10.9\end{array}$ & $\begin{array}{c}1.157 \mathrm{wt} \% \\
\text { in water } \\
\text { at } 25^{\circ} \mathrm{C}\end{array}$ & -4.1 & Negligible \\
\hline $\begin{array}{c}2,4- \\
\text { (Dichlorophenoxy) } \\
\text { acetic acid } \\
(2,4-\mathrm{D})\end{array}$ & $\mathrm{H}_{2}-\mathrm{COOH}$ & 3.2 & \begin{tabular}{|}
$4.8 \mathrm{mg} \mathrm{L}^{-1}$ \\
$\left(20^{\circ} \mathrm{C}-\right.$ \\
nonionised, \\
est.)
\end{tabular} & 3.2 & $\begin{array}{l}1 \times 10^{-5} \\
\left(20^{\circ} \mathrm{C}\right)\end{array}$ \\
\hline
\end{tabular}

Table 1. Structure and some physicochemical properties of the selected herbicides (Roberts, 1998).

As stressed by Sparks (2003), isotherms are only descriptions of macroscopic data and do not definitively prove a reaction mechanism. Mechanisms must be gleaned from molecular investigations, e.g. the use of spectroscopic techniques. However, the fit of experimental data with theoretical and/or empirical equations for adsorption isotherms is very useful in determining some parameters that provide information on the strength of soil-herbicide interaction, which will give an idea of the bioavailability of the herbicide in a particular soil. There are several adsorption isotherms equations applied to soils and sediments (Haws et al., 2006; Hinz, 2001). In this chapter, only the simplest and most widely applied equations are discussed.

\subsubsection{Linear equation}

The linear, or partitioning equation is expressed as (Pateiro-Moure et al., 2009; Cooke et al., 2004):

$$
q=K_{d} C
$$

where $\mathrm{K}_{d}$ is the partition coefficient and $\mathrm{q}$ and $\mathrm{C}$ as defined above. The parameter $\mathrm{K}_{d}$ provides a measure of the ratio of the amount of material adsorbed to the amount in solution. The higher the value of $\mathrm{K}_{d}$, the greater the affinity of the herbicide for the surface, resulting in lower bioavailability. The problem with the application of this equation is that 
linear behavior of the system in the range of concentrations of interest must be proved. If experimental data do not show a linear response in all the concentration range, the use of $\mathrm{K}_{d}$ values obtained from linear regression will cause over- or underestimation of the true behavior in the non-linear ranges. Calculating $\mathrm{K}_{d}$ with only a pair of values $(\mathrm{C}, \mathrm{q})$ may not be very useful to evaluate bioavailability across a range of environmentally relevant concentrations. It is recommended to perform an adsorption isotherm in the range of concentrations of interest, to test for linearity. Since adsorption of hydrophobic organic pollutants has been shown to be well correlated with the organic carbon content of soil and relatively independent of other soil properties, $\mathrm{K}_{d}$ is sometimes expressed on the basis of TOC (Laor et al., 1996):

$$
K_{O} C=\frac{K_{d}}{0.01 T O C}
$$

where TOC is expressed in \% units.

Most experimental data do not respond to the linear equation; the most common models that describe non-linear adsorption isotherms are the Freundlich equation and the Langmuir equation.

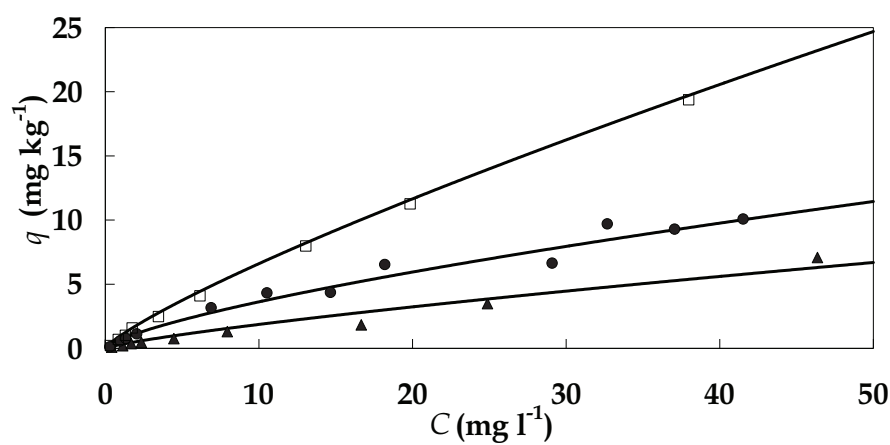

Fig. 2. Binding isotherms at $\mathrm{pH}=6$ for samples with different $\mathrm{TOC} \% .4 .02 \%$ (empty squares), $2.18 \%$ (filled circles), $0.98 \%$ (filled triangles). From Zanini et al. (2009).

\subsubsection{Freundlich equation}

The Freundlich equation is perhaps the most widely applied model in environmental soil chemistry to describe nonlinear sorption behavior (Valverde-García et al., 1998; Kibe et al., 2000). It is an empirical adsorption model (Stumm, 1992; Sparks, 1986) and it can be written as:

$$
q=K_{f} C^{1 / n}
$$

Where, $\mathrm{K}_{f}$ is the distribution coefficient and $\mathrm{n}$ is a correction factor. The lines of Figure 2 have been drawn according to the Freundlich equation. The fitting parameters are present in Table 2 and discussed below. It is important to note that when $n=1$ Equation (4) becomes Equation (2) and $\mathrm{K}_{f}=\mathrm{K}_{d}$. In addition, when $\mathrm{C}$ is equal to unity the distribution coefficient gives the amount adsorbed at that concentration.

While researchers have often used the $K_{f}$ and $1 / n$ parameters to make conclusions concerning mechanisms of adsorption, and have interpreted multiple slopes from 
Freundlich isotherms as evidence of different binding sites, such interpretations are speculative (Sparks, 2003). This is especially true in very complex and heterogeneous systems such as those formed by soil particles. For these systems, fitting of experimental data with isotherm equations should only be used for comparative purposes and to give some interpretation of the shape of the isotherms. Comparison of parameters should be performed with caution. It is necessary to be sure that the $\mathrm{K}_{f}$ values present the same units. The best way to avoid mistakes is to compare different sets of experimental data made under the same conditions and with isotherms performed in the same units of concentration. As in the case of the linear equation, parameters derived from the Freundlich equation should not be used to predict for behavior outside of the range of experimental data.

\subsubsection{Langmuir equation}

This model has been employed in many fields to describe sorption on colloidal surfaces (Zanini et al., 2006; Xi et al., 2010). The Langmuir adsorption equation can be written as:

$$
q=\frac{K_{L} C_{b}}{1+K_{L} C}
$$

Where $K_{L}$ is a constant related to the binding strength, $b$ is the maximum amount of herbicide that can be adsorbed (monolayer coverage) and $\mathrm{q}$ and $\mathrm{C}$ were defined previously. This equation has several assumptions that Langmuir (1918) made in its development. Most of these assumptions are not valid for the heterogeneous surface found in soils. However, many researchers used this model to describe adsorption on soils (Gimsing et al., 2007; Ketelsen \& Meyer-Windel, 1999). As with $\mathrm{K}_{f}$ above, $\mathrm{K}_{L}$ is useful for comparative purposes but they do not provide information on reaction mechanisms. Some researchers fit the experimental data with both Langmuir and Freundlich equations to compare methodological approaches (Campbell \& Davies, 1995; Martínez-Villegas et al., 2004).

\subsection{Isotherm parameters and soil properties}

In order to understand the bioavailability of an herbicide it is important to know the factors that affect its adsorption on soil. A good approach is to perform adsorption isotherms under different experimental conditions, and then relate the parameters of the isotherm to the soil properties. This will be demonstrated for a series of data on MM adsorption on the 30 different soils of the semiarid pampean region of Argentina listed in Table 2. As indicated above, the Freundlich equation was applied to this set of data. Table 2 shows the parameters $\mathrm{K}_{f}$ and $\mathrm{n}$ for all soils. All these soils are subject to similar farming practices (no till and production of the same kind of crops), thus the quality of the soil organic matter is expected to be similar, and the adsorptive differences among soils should be mainly given by differences in TOC. In most soils $1 / \mathrm{n}$ is lower than 1 and thus their isotherms are $\mathrm{L}$ shaped (Hunter, 2002) (Table 2). This kind of shape was also found by Pusino et al. (2003) for the adsorption of primisulfuron on soils, suggesting that the affinity of surface sites for MM is decreasing as the surface is becoming populated with MM. It may also suggest a decrease in vacant adsorption sites as MM concentration increases.

It is necessary to be careful when $K_{f}$ values are compared. If the values of $1 / n$ for the different soils are equal or similar, $\mathrm{K}_{f}$ values can be directly compared, and large $\mathrm{K}_{f}$ mean a strong herbicide-soil interaction. However, if the values of $1 / n$ are rather different the comparison is not straightforward. 
Values of $\mathrm{K}_{f}$ and $1 / \mathrm{n}$ were used to calculate the adsorption of $\mathrm{MM}$ at different equilibrium concentration for the 30 analyzed soils. From these calculations, plots relating adsorbed amounts with a given soil property can be constructed. For example, Figure 3 a shows the adsorbed amount at equilibrium concentration of $10 \mathrm{mg} \mathrm{l}^{-1}$ as a function of TOC. A positive and significant relationship between $\mathrm{q}$ and TOC is observed in the Figure. Although not shown here, this positive and significant relationship was found for all the studied concentrations $\left(10,20,30\right.$ and $\left.40 \mathrm{mg} \mathrm{l}^{-1}\right)$. The results show that TOC is a very important factor that affects $\mathrm{MM}$ adsorption in the entire range of $\mathrm{MM}$ concentrations investigated. This is known for other herbicides (Kah \& Brown, 2006; Weber et al., 2002). However, Cramer et al. (1993) found no clear relationship between adsortion of metsulfuron methyl and soil organic matter in Colorado soils, and the adsorbed amount showed only a weak correlation with organic matter content.

\begin{tabular}{|ccccccccc|}
\hline Soils & TOC $\%$ & Sand \% & Clay $\%$ & SSA m2 $g^{-1}$ & $\mathrm{pH}$ & $\mathrm{K}_{f}$ & $1 / n$ & $\mathrm{R}^{2}$ \\
\hline 1 & 0.98 & 53.7 & 28.4 & 8.3 & 7.50 & $0.16(0.01) \mathrm{a}$ & $0.95(0.03) \mathrm{a}$ & 0.99 \\
2 & 1.28 & 64.1 & 25.3 & 3.4 & 5.94 & $0.24(0.04)$ & $0.91(0.05)$ & 0.99 \\
3 & 1.29 & 51.9 & 38.9 & 12.0 & 6.51 & $0.22(0.03)$ & $0.98(0.04)$ & 0.99 \\
4 & 1.40 & 48.5 & 33.9 & 5.2 & 6.05 & $0.54(0.08)$ & $0.74(0.05)$ & 0.95 \\
5 & 1.43 & 56.5 & 28.2 & 4.5 & 6.90 & $0.24(0.09)$ & $1.02(0.10)$ & 0.96 \\
6 & 1.44 & 57.4 & 33.4 & 4.9 & 6.05 & $0.61(0.06)$ & $0.70(0.03)$ & 0.98 \\
7 & 1.58 & 54.5 & 33.4 & 5.4 & 6.51 & $0.22(0.08)$ & $0.86(0.11)$ & 0.94 \\
8 & 1.76 & 44.7 & 41.8 & 7.3 & 6.19 & $0.78(0.12)$ & $0.55(0.05)$ & 0.97 \\
9 & 1.82 & 45.8 & 39.8 & 8.4 & 6.55 & $0.36(0.07)$ & $0.86(0.05)$ & 0.98 \\
10 & 1.88 & 43.7 & 44.2 & 7.9 & 6.47 & $0.74(0.16)$ & $0.68(0.07)$ & 0.96 \\
11 & 1.91 & 50.3 & 41.8 & 4.6 & 6.04 & $0.96(0.29)$ & $0.40(0.09)$ & 0.86 \\
12 & 1.94 & 42.7 & 39.4 & 4.6 & 6.46 & $0.54(0.08)$ & $0.74(0.05)$ & 0.97 \\
13 & 2.06 & 47.2 & 39.2 & 6.1 & 6.77 & $0.20(0.07)$ & $1.02(0.10)$ & 0.97 \\
14 & 2.07 & 44.0 & 38.3 & 5.8 & 6.30 & $0.53(0.13)$ & $0.88(0.08)$ & 0.98 \\
15 & 2.10 & 46.4 & 38.9 & 4.8 & 6.51 & $0.31(0.07)$ & $0.85(0.07)$ & 0.97 \\
16 & 2.18 & 52.7 & 28.2 & 4.6 & 6.90 & $0.78(0.07)$ & $0.69(0.07)$ & 0.98 \\
17 & 2.46 & 52.2 & 35.9 & 3.7 & 6.14 & $0.76(0.27)$ & $0.77(0.10)$ & 0.94 \\
18 & 2.50 & 42.5 & 36.7 & 10.6 & 6.58 & $0.60(0.12)$ & $0.98(0.06)$ & 0.99 \\
19 & 2.56 & 30.7 & 49.7 & 7.7 & 6.59 & $1.18(0.12)$ & $0.55(0.06)$ & 0.93 \\
20 & 2.59 & 32.6 & 44.0 & 5.6 & 6.08 & $0.91(0.12)$ & $0.69(0.04)$ & 0.91 \\
21 & 2.75 & 36.1 & 40.9 & 5.6 & 5.80 & $0.84(0.21)$ & $0.65(0.08)$ & 0.97 \\
22 & 2.88 & 43.0 & 35.4 & 5.2 & 6.44 & $0.56(0.10)$ & $0.92(0.06)$ & 0.98 \\
23 & 2.93 & 31.2 & 48.6 & 5.2 & 7.80 & $0.36(0.11)$ & $0.80(0.09)$ & 0.96 \\
24 & 3.07 & 47.2 & 33.7 & 4.3 & 6.36 & $1.07(0.25)$ & $0.67(0.07)$ & 0.96 \\
25 & 3.10 & 45.3 & 33.9 & 4.4 & 7.10 & $0.61(0.14)$ & $0.69(0.07)$ & 0.98 \\
26 & 3.34 & 50.4 & 30.6 & 9.0 & 6.51 & $0.85(0.16)$ & $0.89(0.06)$ & 0.98 \\
27 & 3.91 & 46.5 & 31.2 & 5.5 & 6.10 & $1.10(0.32)$ & $0.79(0.09)$ & 0.99 \\
28 & 4.02 & 52.0 & 28.6 & 6.1 & 6.65 & $0.96(0.05)$ & $0.83(0.02)$ & 0.99 \\
29 & 4.62 & 61.4 & 25.3 & 4.0 & 5.86 & $0.80(0.15)$ & $0.93(0.06)$ & 0.99 \\
30 & 4.85 & 44.3 & 32.8 & 6.0 & 8.03 & $1.35(0.22)$ & $0.77(0.05)$ & 0.98 \\
\hline
\end{tabular}

Values within brackets correspond to standard error.

Table 2. Selected physical and chemical properties of the studied soils. 
In order to investigate the effects of soil inorganic compounds on the adsorption of MM, the adsorbed amount was also plotted as a function of clay percent (Figure $3 \mathrm{~b}$ ). There is no significant correlation indicating that inorganic compounds are not important on adsorption. The lack of interaction with inorganic compounds is not always the case for the adsorption of sulfonylureas. Pusino et al. (2003), for example, reported that inorganic solids such as amorphous Fe oxides and $\mathrm{Al}^{3+}$ and $\mathrm{Fe}^{3+}$ exchanged montmorillonites were active in adsorbing primsulfuron. The absence of important amounts of Fe oxides and smectites exchanged with trivalent cations in the studied soils (Blanco \& Stoops, 1993) might explain the weak effect that inorganic components have on the adsorption of MM.

The above discussion highlights the variable behavior of MM among soils. These differences may result from variation in the properties of the inorganic compound, organic matter, or other soil properties such as $\mathrm{pH}$. Another important factor to take into account is $\mathrm{pH}$, especially if the herbicide has acid or basic groups. Figure 4 shows the adsorption isotherms of $\mathrm{MM}$ on soil at $\mathrm{pH} \mathrm{4,6}$ and 8. MM adsorption decreases as the $\mathrm{pH}$ increases, in agreement with the general trend observed for sulfonylureas (Hay, 1990). This figure shows that changes in $\mathrm{pH}$ can affect the adsorption of MM. This behavior is usually explained in terms of charge development at the surface of soil particles and speciation of the herbicide in aqueous solutions as a function of $\mathrm{pH}$ (Berglöf et al., 2003). Since the surface charge of soil particles becomes more negative as the $\mathrm{pH}$ increases, the adsorption of the negatively charged MM species becomes less favored by increasing $\mathrm{pH}$ as a consequence of electrostatic repulsion. In addition, although the adsorption of the neutral MM species should not be affected by electrostatics, its concentration decreases with increasing $\mathrm{pH}$, also causing less favorable adsorption with higher $\mathrm{pH}$.
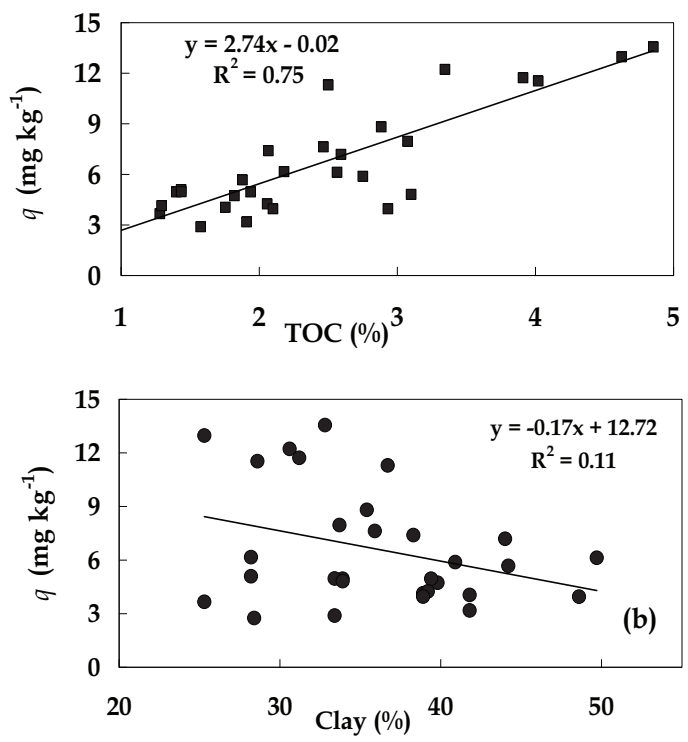

Fig. 3. (a) q (at $20 \mathrm{mg} \mathrm{l}^{-1}$ equilibrium concentration) as a function of TOC \% for data at $\mathrm{pH}=6$.(b) $\mathrm{q}$ (at $20 \mathrm{mg} \mathrm{l}^{-1}$ equilibrium concentration) as a function of the clay content for data at $\mathrm{pH}=6$. 


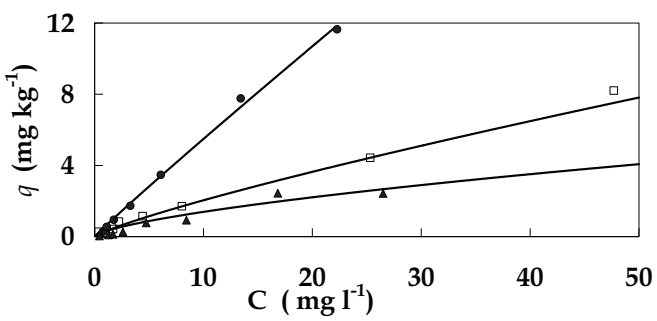

Fig. 4. Binding isotherms at (filled circle) $\mathrm{pH}=4$, (empty square) $\mathrm{pH}=6$, (filled triangle) $\mathrm{pH}=8$. Lines have been drawn according to the Freundlich isotherm. From Zanini et al. (2009).

Some of the parameters obtained from adsorption isotherms are useful for an indirect estimation of the mobility of herbicides in soils. This can be obtained from the groundwater ubiquity score, GUS (Gustafson, 1989) defined as:

$$
\text { GUS }=\log t_{1 / 2}\left(4-\log K_{O C}\right)
$$

where GUS is a dimensionless index, $t_{1 / 2}$ is the herbicide half-life in soil and $K_{O C}$ was defined previously (Equation 3). According to Oliveira Jr. et al. (2001) herbicides with GUS < 1.8 are ranked as non-leachers, those with GUS $>2.8$ are leachers, whereas those with $1.8<$ GUS $<2.8$ are considered transitional. It must be remarked that $t_{1 / 2}$ values should be measured for the specific soil under study because it may change greatly from soil to soil (Juhler et al., 2008; Bedmar et al., 2006).

In summary, it can be stated that adsorption depends on the physicochemical characteristics of the herbicide and the particular soil properties. In order to understand the processes that affect the bioavailability of an herbicide it is necessary to perform adsorption isotherms with the soils under study. Since adsorption and bioavailability change greatly from one soil to another, literature data can help to understand the general behavior of an herbicide, but they cannot give specific information about the behavior on a particular soil. Another important conclusion is that the mobility of an herbicide cannot be assessed only by knowing its physicochemical data. It is also very important to consider the presence of microorganisms in the soil system, as they can significantly affect the value of $\mathrm{t}_{1 / 2}$ in Equation 6 .

\subsection{Spatial distribution of microbial populations}

As discussed earlier, soil is characterized by the heterogeneity in physicochemical and structural characteristics that provide many different micro-habitats for microbial life. The distribution of soil microorganisms varies both horizontally and vertically and from the micro site (few millimeters) to the regional (kilometers) scale. The abundance and diversity of most soil organisms are highest in the top $0-10 \mathrm{~cm}$ of soil and decline with depth in parallel with organic matter contents, the source of energy, nutrients and carbon (C) for the vast majority of soil microorganisms. Most microorganisms are located surrounding the water layer attached to soil particles within micro-aggregates. Pallud et al. (2004) estimated that soil bacteria occupy only $0.1 \mathrm{~mm}^{3}$ of the $500 \mathrm{~mm}^{3}$ of pores in $1 \mathrm{~cm}^{3}$ of soil. Moreover, different physiological groups present at the same density in soil might have significantly different microscale spatial distributions (e.g., forming clumps of cells in a few "hot spots" versus evenly spread out across soil particle surfaces).

Biodegradation of herbicides constitutes a clear example of the importance of understanding the spatial distribution of soil microorganisms. Spatial variability in both glyphosate 
mineralization and general soil microbial characteristics, was observed even across small areas (decimeter scale) within a single field in two Norwegian sandy loam soils (Stenrød et al., 2006), reflecting the importance of soil physicochemical parameters controlled by surface topography. Similarly, Vieuble-Gonod et al. (2005) reported that potential for 2,4-D mineralization was heterogeneous from field to microhabitats. High mineralization potential was not distributed randomly in the soil, but rather as systematic hot spots organized at centimeter scales (Vieuble-Gonod et al., 2005). Most pesticides may represent an occasional source of $\mathrm{C}$ and nutrients for soil microorganisms, so they can be completely dissipated from the soil environment by either a single microbial species or the joint action of a microbial consortium. In the later case, the degradation pathway in soil involves the cooperative activity of several strains that possess enzymes that catalyze different degradation steps. This cooperation is only possible with intimate contact between microbial cells and their substrates, as metabolites resulting from one step of the pathway may act as substrate for a different strain. Moreover, the bacterial distribution at the microscale may facilitate spreading of degradative genes located in plasmids or transposons (McGowan et al., 1998; DiGiovanni et al., 1996). Pallud et al. (2004) found that for low abundances of 2,4 D degraders, there was strong spatial isolation within the degraders populations, with less than 2 cells per colonized patch. 2,4-D amendment caused an increase in degrader abundance and concurrent spreading of degraders, reducing the distance between colonized patches, although the number of cells per patch remained low $(<28)$. They argued that the spatial spreading of bacteria was an ecological strategy that increased the probability of encountering the substrate $(2,4-\mathrm{D})$, and proposed that this was achieved either through active cell movement (chemotaxis) or degradative plasmids transfer to indigenous microbial populations (Pallud et al., 2004).

The zone of soil directly influenced by the presence of plant roots, known as rhizosphere, is of particular importance. Plant roots act on microbes essentially through the input of a wide variety of organic compounds (e.g., sugars, amino acids, cellulose, proteins, phenolic acids), known as rhizodeposition, and by providing a surface for attachment, creating an environment that can greatly differ from the surrounding bulk soil. As a consequence, higher microbial biomass and activities are found in the rizosphere as opposed to bulk soil. Several studies have reported that rhizosphere enhances biodegradation of chlorophenoxyacetic acids (Shaw \& Burns, 2004; 2005; Merini et al., 2007), metsulfuronmethyl (Ghani \& Wardle, 2001) and atrazine (Piutti et al., 2002). Biodegradation pathways and strategies will be discussed in the following section.

\subsection{Biodegradation: co-metabolism vs. growth-linked metabolism}

Biodegradation is the enzyme-mediated transformation of a xenobiotic by living microbial cells. In soil systems, biodegradation is a fundamental attenuation process for pesticides and is controlled by biotic factors (i.e. microbial activity) and a number of physicochemical processes such as sorption and desorption, diffusion, and dissolution (Chen et al., 2009). Pesticide degradation by microorganisms that are capable of using the chemical as a source of $\mathrm{C}$ and energy for growth, is called mineralization. This metabolic strategy results in the complete dissipation of the chemical and its conversion to $\mathrm{CO}_{2}$, water and inorganic elements. In this case, the biomass of the degrading population increases at the expense of the substrate. The rate of change in herbicide concentration in the medium follows the dynamic of the expanding microbial population, i.e., as the herbicide concentration decreases in the solution, growth of the microbial population reaches a plateau at a high cell density. Conversely, the partial transformation of an herbicide by microorganisms that gains 
no $\mathrm{C}$ or nutrients and energy, is called co-metabolism. In most cases, co-metabolism of herbicides involves microbial growth at the expense of a co-substrate that provides $C$ and energy, but the pesticide in itself does not support microbial proliferation. The biomass of the herbicide degrading microbial population and the concomitant rate of herbicide degradation is not affected by the herbicide concentration in solution. Even though an herbicide may be partially transformed by co-metabolism, intermediate metabolites may be completely degraded by other microorganisms in soil.

\subsubsection{Metabolic pathway of 2,4-D}

One of the most studied herbicide degradation pathways is that of 2,4-D, which can be readily used as a $\mathrm{C}$ and energy source by environmental microorganisms. Numerous 2,4-D degrading bacteria have been isolated and characterized (Tiedje et al., 1969; Don \& Pemberton, 1981; Kamagata et al., 1997; Muller et al., 2001). Most of these strains are members of genera belonging to the $\beta$ and $\gamma$ subdivisions of the class Proteobacteria and were isolated from 2,4-D treated environments (Kamagata et al., 1997; Lee et al., 2005). These $\beta$ and $\gamma$ subgroups carry $t f d$ genes homologous to the canonical genes found in Cupriavidus necator JMP134 (Lerch et al., 2007), the model organism for 2,4-D degradation studies (Figure 5). These genes are located on conjugative plasmids like pJP4 which carries tfdABCDEF (Don \& Pemberton, 1981). On this plasmid, $t f d A$ encodes a 2,4-D/ $\alpha$-ketoglutarate dioxygenase, which transforms 2,4-D into 2,4dichlorophenol (DCP), while $t f d B$ encodes a dichlorophenol hydroxylase that transforms DCP in 3,5-dichlorocatechol. The $t f d C D E F$ operon encodes enzymes involved in the ortho-cleavage of the aromatic ring and subsequent reactions (Fukumori \& Hausinger, 1993a;b; Vallaeys et al., 1996). Zabaloy et al. (unpublished results) recovered several Cupriavidus-like isolates from an agricultural soil in Argentina, able to grow with up to $1.1 \mathrm{mM}$ herbicide as sole $\mathrm{C}$ source with complete primary degradation in $<72 \mathrm{~h}$. These isolates harbored $t f d A$ and $t f d B$ genes similar to the canonical degradation genes described by Vallaeys et al. (1996), as determined by PCR and restriction fragment length polymorphism (RFLP). Recently, isolation of 2,4-D degrading bacteria from pristine environments has unveiled the existence of other degradative genes, namely the $c a d R A B K C$ operon, which are responsible for 2,4-D catabolism in slow-growing Proteobacteria (Kitagawa et al., 2002).

Considerably less information is available regarding 2,4-D degradation by fungi. Donnelly et al. (1993) reported that the basidiomycete Phanerochaete chrysosporium was able to degrade 2,4-D when provided with external nitrogen sources. Vroumsia et al. (2005) screened the ability of ninety strains of filamentous fungi to degrade the herbicide in liquid media, finding that 2,4-D was less accessible to degradation than its metabolite DCP, although both compounds were inefficiently used. The kinetics studies performed on the most efficient strains revealed a one-day lag phase before 2,4-D degradation and no lag phase for DCP.

2,4-D application to agricultural soils triggers specific degradation pathways in existing degrading bacterial populations (Baelum et al., 2006; 2008). Degradation of 2,4-D in soil initially occurs at low rates, as the specific degrading population increases in size. During that 1-3 day period, which corresponds to the lag phase of degraders, 2,4-D degradation probably proceeds by co-metabolism in soil (Vieublé-Gonod et al., 2006; Lerch et al., 2009). Zabaloy et al., 2010 examined aerobic degradation of 2,4-D in soil microcosms treated with environmentally-relevant level (ERL, $5 \mathrm{mg} \mathrm{kg}^{-1}$ soil) and high level (HL, $50 \mathrm{mg} \mathrm{kg}^{-1} \mathrm{soil}$ ) of 2,4-D after 3 and 14 days of incubation, using the BD Oxygen Biosensor System (BDOBS) . The use of 2,4-D as sole source of $C$ and energy $\left(50 \mathrm{mg} \mathrm{l}^{-1}\right)$ was initially retarded $(>40 \mathrm{~h}$ at day 3) and was maximal 2 weeks after treatment (Figure 6). They argued that 


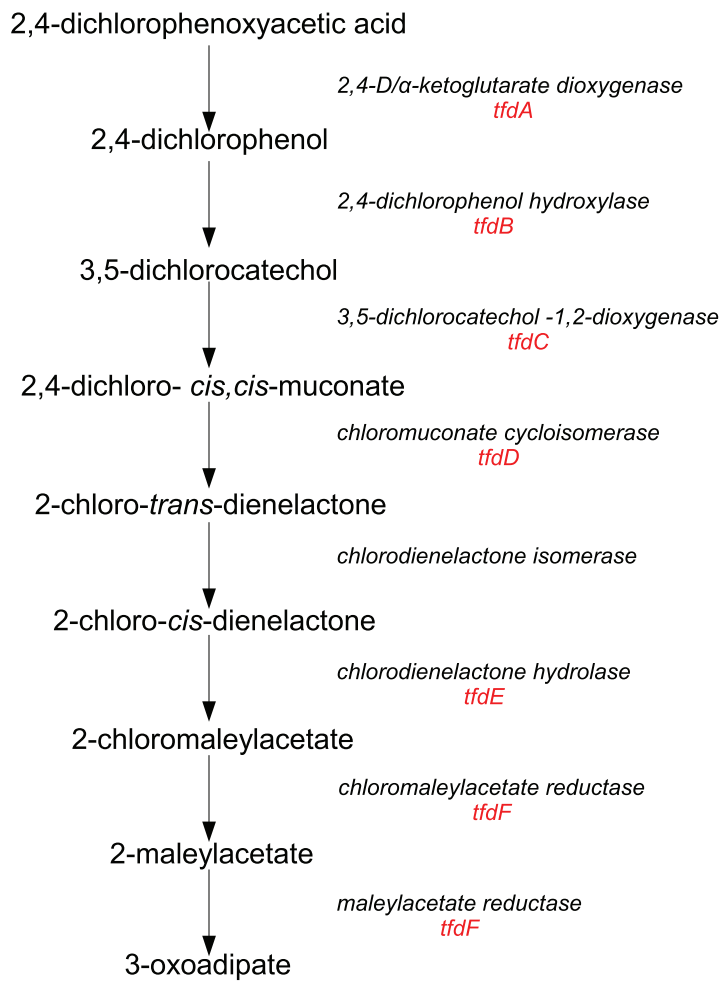

Fig. 5. Metabolic pathway of 2,4-D/ $\alpha$-ketoglutarate dioxygenase acid in Cupriavidus necator JMP134. Adapted from Caspi et al. (2010).

between day 3 and 14 a shift in dominant degrader populations might have occurred in the $\mathrm{HL}$, as opposed to the ERL microcosms, and the increase in use of 2,4-D was reflecting the activity of specific degraders that were favoured by the high dose.

\subsubsection{Metabolic pathways of glyphosate}

Microbial degradation of glyphosate has been extensively explored and several degrading bacteria, belonging to Arthrobacteriaceae, Bacillaceae, Rhodobacteriaceae, Alcaligenaceae, Pseudomonaceae, Enterobacteriaceae and Rizhobiaceae, have been isolated and characterized (Kononova \& Nesmeyanova, 2002). Most degrading isolates posses the capability to use glyphosate as a source of $\mathrm{P}$, once extracellular inorganic phosphate becomes limiting in the environment (McGrath et al., 1997). Bacterial degradation of glyphosate follows either of two metabolic pathways. For example, a C-P lyase catalyzes the breakdown of the C-P bond in Pseudomonas sp. PG2982, releasing inorganic phosphate (Pi) and sarcosine, which is subsequentially mineralized to $\mathrm{CO}_{2}$ and $\mathrm{NH} 4+$ (Kishore \& Jacob, 1987). Glyphosate dehydrogenase catalyzes the conversion of glyphosate to aminomethylphosphonic acid (AMPA) and glioxylate as primary metabolites in Geobacillus caldoxylosilyticus T20, and a C-P lyase releases Pi from AMPA afterwards (Obojska et al., 2002). Although bacteria are considered as the main biological degrader of glyphosate in soils, fungi also may be important (Singh \&Walker, 2006). Krzyko-Lupicka \& Orlik (1997) 


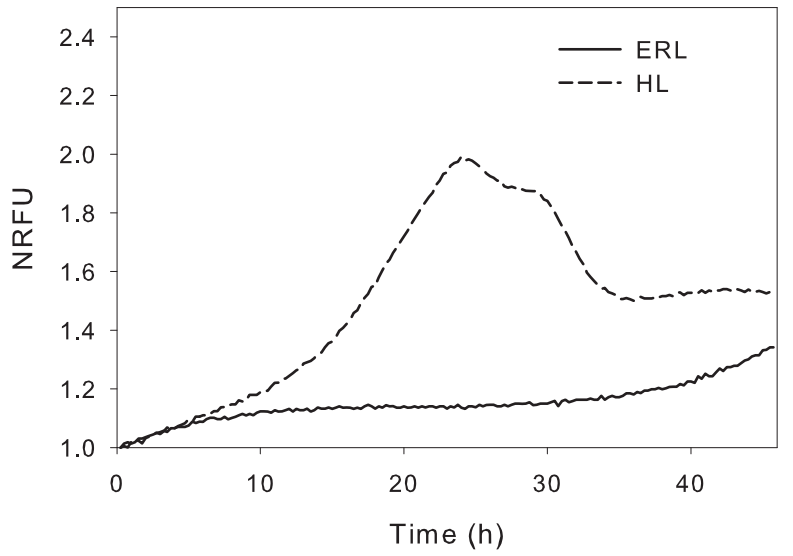

Fig. 6. Fluorescence curve (i.e., oxygen consumption) in BDODS plate with 2,4-D as sole source of $\mathrm{C}$ and energy, in 2,4-D-acclimated soil slurries after 14 days of incubation. Microcosms received 5 and $50 \mathrm{mg} \mathrm{kg}^{-1}$ soil of 2,4-D (ERL and HL). NRFU= normalized relative fluorescence units. From Zabaloy et al., 2010.

reported that the diversity of species isolated from soil diminished in media containing glyphosate, with a predominance of strains of Mucor, Fusarium and Trichoderma. Almost all the tolerant species isolated grew well when glyphosate was used as the unique source of $\mathrm{P}$, but only a few were able to grow on it as the sole C source. Glyphosate also served as a nitrogen source for a Penicillium chyrsogenum strain isolated from soil (Lipok et al., 2003) and as $C$ source for indigenous yeasts isolated from treated and untreated soils (Romero et al., 2004). Two yeast species were identified as active biodegraders (Yarrowia lipolitica and Candida krusei) but failed to uptake the herbicide when phosphate was present, suggesting that glyphosate was important for C and P nutrition in the yeasts (Romero et al., 2004).

Glyphosate degradation in soil is predominantly a co-metabolic process, as it is not used as a $\mathrm{C}$ and energy source by the vast majority of microorganisms (Forlani et al., 1999; Singh \& Walker, 2006). As opposed to degradation in pure-culture experiments, glyphosate degradation in soil occurs without a lag phase, further suggesting a co-metabolic process as enzymes were present in soil before the application of the herbicide (Borggaard \& Gimsing, 2008). Moreover, no adaptation to glyphosate degradation has been observed in soils with long histories of herbicide treatment (Gimsing et al., 2004). Lancaster et al. (2009) reported that the total amount of ${ }^{14} \mathrm{CO}_{2}$ evolved from glyphosate was reduced with repeated herbicide applications compared to a single application, which proved that biodegradation was not enhanced (i.e., no evidence of accelerated degradation) and was probably the result of a co-metabolic process. It is not well-known which metabolic pathway prevails in soils (Borggaard \& Gimsing, 2008) although most isolated bacteria (Liu et al., 1991; Kishore \& Jacob, 1987) and fungi (Sailaja \& Satyaprasad, 2006) possess the sarcosine pathway. Even though AMPA is the main metabolite detected in soil, this could be attributed to the rapid mineralization of sarcosine and the persitance of AMPA in the environment.

\subsubsection{Biodegradation of metsulfuron-methyl}

Many studies have focused on the environmental fate and behavior of metsulfuron-methyl, but research on microbial degradation is still scarce. Zanardini et al. (2002) isolated a 
Pseudomonas strain that degraded metsulfuron through co-metabolism and Boschin et al. (2003) studied the degradation pathway in the common soil fungus Aspergillus niger. Yu et al. (2005) isolated a Curvularia sp. capable of using the herbicide as a sole source of $C$ and energy and studied several features of herbicide degradation in pure culture and in soils. Vázquez et al. (2008) isolated several filamentous fungi able to grow with metsulfuron as sole source of $\mathrm{C}$ and energy. Only Penicillium and Trichoderma strains were able to complete their life cycle in metsulfuron-containing medium. Trichoderma strains showed the best capacity to grow using the herbicide and were selected to perform tolerance assays; all could grow from spores in minimal medium containing metsulfuron and two showed heavy sporulation with increasing concentrations (up $1 \times 10^{-2} \mathrm{ppm}$ ) (Vázquez et al., 2009). He et al. (2007) inoculated wheat rhizosphere with a highly effective metsulfuron-degrading Penicillium sp., previously isolated from treated soil, reporting that the inoculation enhanced the degradation of the target herbicide. Regardless of the pure-culture experiments that showed microbial degradation of metsulfuron methyl, limited mineralization of this herbicide in soil has been reported (Pons \& Barriuso, 1998; Andersen et al., 2001). Ghani \& Wardle (2001) studied ${ }^{14}$ C-labeled metsulfuron-methyl in soil-plant microcosms and reported that $42 \%$ of the applied metsulfuron was respired or incorporated into microbes in the planted treatment while $36 \%$ was used in the unplanted system by day 131 . They argued that greater utilization of metsulfuron in the planted microcosm would have been influenced largely by a greater microbial biomass in that treatment. Despite the positive rhizosphere effect on herbicide mineralization, more than $50 \%$ was still present in soil even four months after an application at recommended rates.

\section{Approaches to link bioavailability and biodegradation}

Bioavailability is influenced by a variety of factors, including physical characteristics of the sorbent (e.g., particle shapes, sizes, and internal porosities), chemical properties of the sorbates and sorbents, and biological factors (e.g., microbial density and degradative capacity). Generally, sorbed compounds are assumed to be less accessible to attached or suspended microorganisms, which preferentially or exclusively utilize herbicides in the aqueous phase. In this view, herbicide is available for biodegradation only after desorption, followed by diffusion into solution. The sorbed fraction remains protected from microbial attack as a result of: 1) physical sequestration of the herbicide in the organo-chemical matrix, 2) chemical stabilization in the sorbent surface, and/or 3) reduction of aqueous-phase concentrations to levels that do not sustain microbial growth (Ainsworth et al., 1993; Lerch et al., 2009). However, some other investigations revealed that silica-sorbed 2,4-D (Park et al., 2001) and soil-sorbed atrazine (Park et al., 2003) can be directly utilized by degrading bacteria. Park et al. (2001) proposed two plausible explanations for the observed enhanced bioavailability of silica-sorbed herbicide: 1) attached biomass is able to access adjacent elevated concentrations of herbicide before complete dilution in the liquid phase; 2) attached cells are capable of higher metabolic rates. Similarly, soil organic matter is implicated in sorption processes and therefore, affects the availability of herbicides to degrading microbes (Benoit et al., 1999). This section will briefly present recent research approaches that have been successfully used to link bioavailability and degradation of herbicides.

Benoit et al. (1999) studied the degradation of ${ }^{14} \mathrm{C}$ ring-labeled 2,4-D and two chlorophenols, adsorbed on different organic materials (wood chips, straw, lignin, humic acids) and 
aluminum oxide in soil incubations. They observed that mineralization of these compounds, when incubated in direct contact with soil, varied greatly according to the nature of the sorbent, but was generally higher in more humified organic matter (humic acid) than in less transformed organic matter (wood, lignin and straw). However, separation of chemicalsorbent associations from soil during incubation in polyamide bags with non-decomposed and composted straw showed higher mineralization levels than in direct touch with soil for all compounds, despite slower mineralization rates. They proposed that straw-associated microorganisms actively degraded 2,4-D and chlorophenols. Schnürer et al. (2006) tested the effect of surface sorption on the bioavailability of glyphosate by adding goethite to an organic soil, and using respirometric and attenuated total reflectance Fourier transform (ATR-FTIR) spectroscopy approaches. Addition of goethite reduced the negative effects of glyphosate on microbial respiration, as surface sorption reduced toxic effects of the herbicide or its metabolites. However, ATR-FTIR data showed that sorbed herbicide was bioavailable and was degraded despite the reduction in soil respiration in the presence of glyphosate. Hermosín et al. (2006) evaluated the bioavailability of organoclay-based formulations of 2,4-D for bacterial degradation in pure culture and leaching potential in soil columns. They observed that the rate of mineralization of ${ }^{14} \mathrm{C}-2,4-\mathrm{D}$ from the organoclay complexes was related to the rate of release from the complexes, suggesting that desorption into the aqueous phase was the limiting step for biodegradation. The organoclay-based formulations reduced the leaching losses of 2,4-D in soil columns, and the amount of herbicide leached was considerably less than the amounts of 2,4-D mineralized. They concluded that these formulations slowly released 2,4-D, reducing risk of leaching losses in soil, while maintaining accessibility for bacterial degradation. Sørensen et al. (2006) studied sorption and biodegradation of ${ }^{14} \mathrm{C}$-labeled glyphosate and the phenoxyacid herbicide 4chloro-2-methylphenoxy-acetic acid (MCPA) in soil and subsurface samples from a sandy agricultural site and a clay rich till in Denmark. These authors observed that MCPA sorbed to a minor extent and was mineralized rapidly in most samples, except in the deepest layers at both sites, and no relation was found between sorption and mineralization for this herbicide. Interestingly, the highest extent of mineralization of MCPA occurred in the top soil which coincided with the largest sorption and lowest desorption. Conversely, samples which showed higher sorption and low desorption exhibited no or reduced mineralization of glyphosate indicating a limited glyphosate bioavailability. Lerch et al. (2009) assessed the link between bioavailability and mineralization of ${ }^{13}$ C-2,4-D over a 6-month study, by using stable isotope probing (SIP) coupled to fatty acid methyl ester (FAME) to study degrader populations. These authors reported that the proportion of readily available (water extracted) as well as potentially available (solvent extracted) herbicide residues decreased rapidly to less than $1.2 \%$ of the initial amount added to soil at day 8 , which corresponded to the period of highest biodegradation activity. From day 8 onwards, labelled C-2,4-D was present in the form of non-extractable residues (NER), which nontheless were biodegradable. The ${ }^{13} \mathrm{C}-2,4-\mathrm{D}$ enriched FAME profiles during this period of incubation were similar to those of the populations degrading 2,4-D when it was still available. They proposed that either the degradation of NER was due to the activity of the same specific degraders involved in degradation of available 2,4-D, limited by desorption of ${ }^{13} \mathrm{C}-2,4-\mathrm{D}$ in the soil solution, or that specific degraders were present in a dormant state and/or their fatty acids were being recycled by cells from the same taxonomical group. Overall, these studies show that while adsorption-desorption phenomenons affect bioavailability, there is evidence that sorbed herbicides may be accessible for biodegradation. 
The above discussion has practical implications, when predicting the potential in situ biodegradation of a certain herbicide. In the field, additional factors other than presence of potential degraders and bioavailability must be considered, including the 1) presence of other contaminants that can compete for adsorption sites and for access to microbial enzymes (Haws et al., 2006); 2) availability of nutrients and co-factors necessary for degraders growth and activity; 3 ) intrinsic environmental factors (e.g., temperature, oxygen concentration, surface charge, water availability, $\mathrm{pH}$, etc.). The presence and nature of crop residues should also be considered, as they can have great impact on the bioavailability of herbicides in the agroecosystem, helping reduce hazardous effects on soil and water resources (Benoit et al., 1999).

\section{How to assess the impact of herbicide exposure on soil microbial communities}

Although the desorption of an herbicide from soil particles into the aqueous phase facilitates its biodegradation, the bioavailable fraction is also a potential risk for non-degrading microbial populations. Microbial-mediated processes in soils are of critical importance to ecosystem functions, including transformation of organic matter, nutrient release and degradation of xenobiotics. Therefore, an active soil microbial population is considered a key component of good soil quality (Parkin et al., 1996; Pell et al., 2006). Several biological parameters have been used to assess soil quality and health as affected by agricultural practices (Anderson, 2003; Benedetti \& Dilly, 2006). Microbes are expected to be more effective indicators than physical and chemical parameters as they are able to respond immediately to environmental changes (Nannipieri et al., 2002).

The effects of pesticides on the microbiota can be assessed at the whole community-level (e.g., respiration, enzyme activities, biomass, total bacteria counts, etc.) or at sub-community level (i.e., specific physiological or phylogenetic groups). The use of molecular tools has greatly improved the ability to detect pesticide-induced changes, as they allow better resolution of the microbial community structure. The recommended approach for assessing the effects of pesticides on microbial communities is the simultaneous measurement of multiple ecological, structural and functional end points in soil microcosms or terrestrial model ecosystems, rather than reliance on a single assay (Nannipieri et al., 2002; Burrows \& Edwards, 2004; Joergensen \& Emmerling, 2006). It should be noted that there is little value in assessing the effects of unrealistically high herbicide concentrations in agricultural soils, as there is no reason to expect that those levels would be reached under normal agricultural use. This section is not intended to be an extensive literature review, but rather show the considerable variation in response among soil microbial communities and the diversity of parameters available to assess potential negative impacts of herbicides on the microbiota.

\subsection{Microbial respiration}

Besides being a generally accepted measure of total soil microbial activity, respiration has been used as a sensitive indicator of pesticide and heavy metal toxicity (e.g. Anderson (2003); Yao et al. (2006)). Zabaloy \& Gómez (2008) observed that metsulfuron methyl at 100 $\mu \mathrm{g} \mathrm{kg}-1$ soil depressed cumulative respiration (measured as evolved $\mathrm{CO}_{2}$ at the end of the 6 weeks incubation) in a Typic Haplustoll [TH] soil while it had no effect in a Petrocalcic Paleustoll [PP] soil, even at a dose of $10 \mathrm{mg} \mathrm{kg}^{-1}$ soil. Similar results have been reported by 
Dinelli et al. (1998) and Accinelli et al. (2002) in soils amended with low doses of sulfonylurea (triasulfuron, primisulfuron methyl and rimsulfuron). Zabaloy \& Gómez (2008) proposed that the lower tolerance of the microbial community of $\mathrm{TH}$ soil was the result of low adsorption and degradation of herbicide due to higher $\mathrm{pH}$ in $\mathrm{TH}$ soil (7.4) compared to PP (6.1) (Figure 7). Phytotoxic effects of metsulfuron have been reported in soils with high $\mathrm{pH}$ (Walker et al., 1989). Higher degradation of metsulfuron methyl in acidic soils compared to alkaline soils is due to the combined actions of chemical hydrolysis and microorganisms (Pons \& Barriuso, 1998; Andersen et al., 2001). No mineralization of either metsulfuron methyl or tribenuron methyl was observed in soils of $\mathrm{pH}>8$, unless the compounds have been pre-hydrolyzed (Andersen et al., 2001). Several studies reported that the effects of glyphosate and 2,4-D on microbial respiration at low rates, equivalent to agronomic doses, are negligible (e.g. Wardle \& Parkinson (1990); Busse et al. (2001); Zabaloy \& Gómez (2008)).

(a)

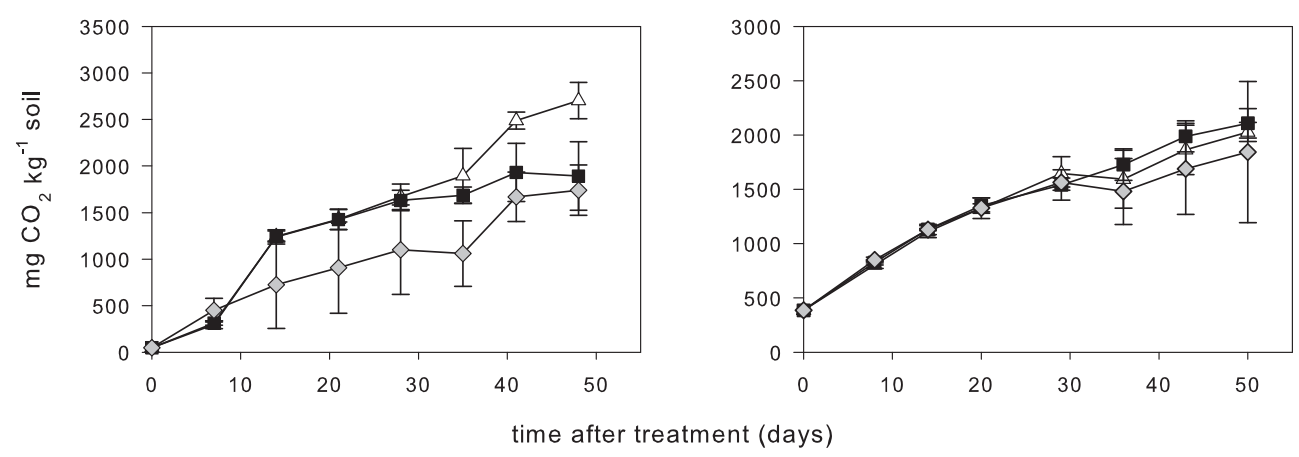

Fig. 7. Effect of two rates of metsulfuron methyl on cumulative $\mathrm{CO}_{2}$ evolution of Typic Haplustoll (a) and Petrocalcic Paleustoll (b) soils. Symbols: (filled squares) $0.01 \mathrm{mg}$ a.i. $\mathrm{kg}^{-1}$ air-dried soil; (gray diamonds) $0.1 \mathrm{mg}$ a.i. $\mathrm{kg}^{-1}$ air-dried soil; (empty triangle) control (distilled water). Error bars indicate standard deviation. Error bars not shown were smaller than the symbols. From Zabaloy \& Gómez (2008)

\subsection{Enzyme activities}

Many studies have shown that enzyme activities are sensitive enough to detect the effects of soil pollutants, including heavy metals (Avidano et al., 2005), insecticides (Yao et al., 2006) and herbicides (Sannino \& Gianfreda, 2001). Dehydrogenases exist as an integral part of intact cells and represent the oxidative activities of soil microbes, whereas fluorescein diacetate (FDA) hydrolysis can be catalyzed by intracellular and extracellular lipases, esterases and proteases produced by microorganisms (Shaw \& Burns, 2006). Both are wellestablished methods to measure the microbial mineralizing capacity in soil and are suitable to assess broad-spectrum biological activity in the short-term (Nannipieri et al., 2002).

Zabaloy et al. (2008) reported that metsulfuron-methyl and 2,4-D had transient, relatively small $(<25 \%$ change from control) effects on soil enzyme activities within two weeks after herbicide addition. While both herbicides induced an early reduction in FDA, 2,4-D also stimulated DHA in the different soils analyzed. In contrast, glyphosate caused a significant reduction (50\%) of intracellular dehydrogenase activity, suggesting a strong influence on bacterial metabolism (Zabaloy et al., 2008). Metsulfuron-methyl at comparable doses 
inhibited urease, amylase and protease activities in loamy sand and clay loam soils (Ismail et al., 1998). There is general agreement on the lack of significant effects of agricultural rates of metsulfuron (Dinelli et al., 1998; Accinelli et al., 2002) and 2,4-D (Frioni, 1981;Wardle \& Parkinson, 1990) on different enzymes. Variable effects of glyphosate and glufosinate on soil enzymatic activities have been reported. In general, literature reports mainly stimulatory effects of glyphosate on enzyme activities for doses within a range of 2-200 mg a.i. $\mathrm{kg}^{-1}$ soil (Sannino \& Gianfreda, 2001; Accinelli et al., 2002; Araújo et al., 2003; Lupwayi et al., 2007).

\subsection{Microbial biomass and abundance}

The number and biomass of microorganisms are basic properties of ecological studies, and which can be related to parameters describing microbial activity and soil health (Bölter et al., 2006). Substrate-induce respiration is a commonly-used, sensitive parameter for the observation of pollutant impacts on soil microorganisms (Brohon et al., 2001). Under standardized conditions, the metabolism of glucose added in excess is limited by the amount of active aerobic microbes in soil. Initially, there is no microbial growth and the respiratory response is proportional to glucose-responsive microbial biomass already present in soil (Höper, 2006). The glucose-responsive and more active part of the microbial community, determined by the SIR biomass, is more sensitive to pollutants than the total microbial biomass, as measured biochemically (Höper, 2006; Chander et al., 2001; Zabaloy et al., 2008).

The number of physiological groups of bacteria has also proved to be useful to measure structural changes in soil due to several anthropogenic factors. Glyphosate is an organophosphonate that can be used as a source of $\mathrm{P}, \mathrm{C}$ or $\mathrm{N}$ by either gram-positive or gram-negative bacteria (van Eerd et al., 2003). Accordingly, increases in bacterial abundance and biomass (Zabaloy et al., 2008) and fungal counts (Araújo et al., 2003; Ratcliff et al., 2006) after glyphosate doses comparable to field rates have been observed. Supporting the hypothesis of a bacterial role in glyphosate dissipation, Gimsing et al. (2004) found a high correlation between glyphosate mineralization rates and Pseudomonas spp. counts in five different Danish soils. Moreover, two soils with high glyphosate mineralization rates also showed high CFU counts (Gimsing et al., 2004). Conversely, low rates of 2,4-D (<10 mg kg-1 soil) have no effects on heterotrophic bacteria counts (Ka et al., 1995; Merini et al., 2007; Zabaloy et al., 2010). The abundance of cellulose degraders and Azotobater were reported to decrease with 2,4-D treatment (Frioni, 1981), although the dose used was several times higher than the expected concentration in soil after a field rate application.

\subsection{Microbial community structure}

Community structure could be defined as the abundance and proportion of distinct phylogenetic and functional groups. Functional groups are defined by the substrates used for energy metabolism (Pankhurst et al., 1996). Community-level end points may not be sensitive enough to detect minor shifts in microbial community structure, due to the inherent functional redundancy that is recognized to exist in soil microbial communities. The disappearance of a certain member of the microbial community as a result of herbicide (or other pollutant) exposure may eliminate key ecosystem functions and/or impair the ability of the microbial community to respond to other environmental perturbations (i.e., reducing resilience). Physiological, biochemical or genetic profiling methods give insight of such potential shifts at the subcommunity level. Popular methods include community-level physiological profiles 
(CLPP), phospholipids fatty acid analysis (PLFA), and various DNA fingerprint techniques (e.g. denaturing or thermal gradient gel electrophoresis [DGGE/TGGE], terminal restriction fragment length polymorphism [T-RFLP]). These and other methods have been summarized in the excellent reviews by Torsvik et al. (1996), Preston-Mafham et al. (2002), Lynch et al. (2004), Kirk et al. (2004), Ogram et al. (2007) and Garland et al. (2007).

Unintended consequences of herbicide applications may be the reduction of sensitive populations and/or stimulation of a certain microbial group with or without detriment to co-existing microbial populations that may compete for available resources. Several investigations that used culture-independent methods reported only slight, short-lived effects of field levels of glyphosate (Weaver et al., 2007; Accinelli et al., 2007) and 2,4-D (Chinalia \& Killham, 2006; Macur et al., 2007; Vieublé-Gonod et al., 2006) on microbial communities. No major changes in community structure, assessed by CLPP and PLFA, occurred with application of field rate concentrations of glyphosate in soils from two pine plantations in California (Ratcliff et al., 2006). Both higher abundance of PLFA biomarkers of gram-negative bacteria (Weaver et al., 2007; Lancaster et al., 2009) and fungal to bacterial biomass ratios (Powell et al., 2009) have been reported in glyphosate-treated soils. In a recent study, Zabaloy et al. (2009) reported minor effects of glyphosate on sole C sources utilization with BDOBS. However, the number of $16 \mathrm{~S}$ ribosomal gene copies, as determined by quantitative PCR (qPCR), increased in a glyphosate-treated soil relative to the control soil, although T-RFLP analysis did not show consistent selective enrichment for specific bacteria species (i.e., no specific phylotype dominated in glyphosate-treated microcosms) (Zabaloy et al., 2009). Due to the enormous diversity of soil microbial communities, more relevant results could be obtained by targeting specific functional groups that are more likely to be directly affected by the herbicide or indirectly by herbicide-induced changes in the soil environment. Interestingly, no effects of glyphosate on denitrifying bacteria nor rhizosphere fungal abundances (qPCR) or communities composition (T-RFLP) have been reported (Hart et al., 2009). Glyphosate was reported to inhibit growth of mycorrhizal fungi and could favor the growth of less desirable fungal species, like soil-borne pathogens (Johal \& Huber, 2009). Krzysko-Lupicka \& Sudol (2008) observed a bias towards the selection of autochtonous Fusarium strains after treatment with the herbicide. This could be related with changes in microbial populations that alter the equilibrium and ultimately lead to diminishing biodiversity, as the postulated decrease in the (pseudomonad) antagonists of fungal pathogens observed by Kremer \& Means (2009) in long-term field studies.

The most noticeable effect of 2,4-D on community structure is the enrichment of degrading populations that use this compound as a source of C and energy. Zabaloy et al., 2010 reported a persistent 2,4-D degrading population able to use the herbicide as $\mathrm{C}$ and energy source in an agricultural soil where herbicide applications had ceased 2 years before the study. The number of degraders increased immediately after treatment of soil microcosms with 2,4- D and remained high until the end of the incubation, while culturable aerobic heterotrophic bacteria counts were not affected by the herbicide (Figure 8). The addition of succinate $(S)$ as an alternative source of $C$ to soil microcosms did not stimulate degrader population, which confirmed that 2,4-D degradation in this soil was mainly a metabolic process performed by specific degraders. Similar results have been obtained by a number of researchers that used a range of herbicide concentrations in different agricultural soils (e.g. Ka et al. (1995); Merini et al. (2007); Macur et al. (2007); Lerch et al. (2009). One practical implication of the proliferation of soil microbes able to degrade some herbicides, such as 
foliar-applied chlorophenoxy acids, is that this phenomenon guarantees self-cleaning of herbicide-impacted agricultural soils, reducing the risk of contamination.

\subsection{Pollution-induced community tolerance}

The pollution-induced community tolerance (PICT) concept is based on the assumption that long-term exposure of a community to a given toxicant will lead to a higher tolerance for this pollutant (Blanck et al., 1988; Blanck, 2002). PICT is tested by collecting intact communities from polluted and reference sites and exposing these communities to contaminants under controlled conditions. Increased community tolerance resulting from the elimination of sensitive species and addition of tolerant species is considered strong evidence that changes were caused by the pollutant. A fundamental step in the PICT measurements is the selection of an ecologically relevant parameter as endpoint that reflects the toxic effects at the community level (Blanck, 2002).
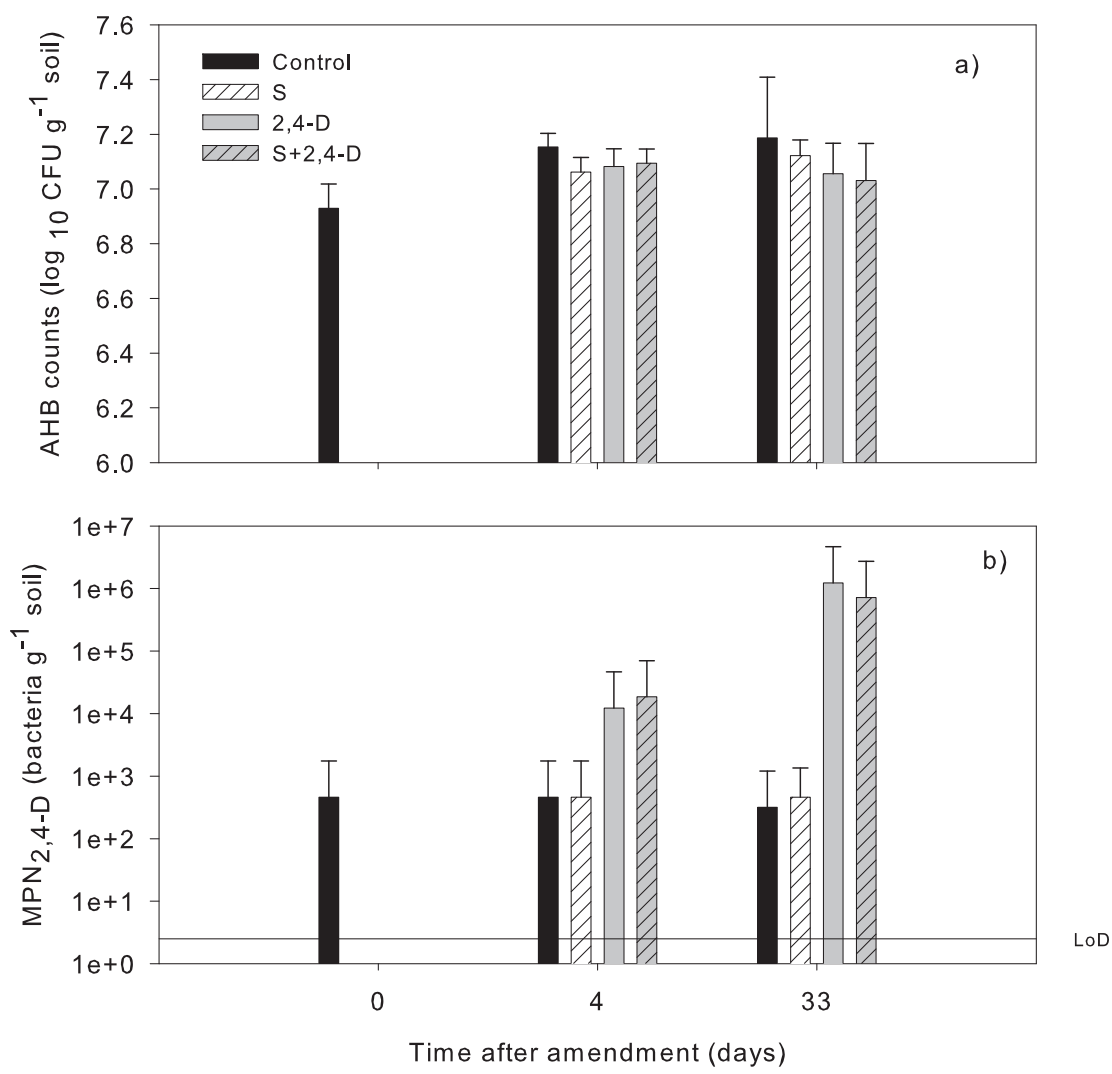

Fig. 8. Effect of combined amendments of 2,4-D and succinate $(S)$ on aerobic heterotrophic bacteria (AHB) counts (a) and most probable number of 2,4-D degraders ( $\left.\mathrm{MPN}_{2,4-\mathrm{D}}\right)$ for soil microcosms sampled after 0,4 and 33 days of incubation. AHB data are given as means \pm S.E $(n=3)$. MPN $2,4-D$ data are represented as median of three replicates and $95 \%$ confidence intervals. LoD, limit of detection. From Zabaloy et al., 2010. 
Microbial activity may be affected by soil characteristics as well as other environmental factors other than contamination. However, increased tolerance to a specific contaminant is less sensitive to variation in physicochemical variables, and more likely a direct result of contaminant exposure (Siciliano \& Roy, 1999; Gong et al., 2000). The PICT approach has been used to study effects of chemicals on microbial communities with various methods such as BiologTM plates (Schmitt et al., 2004), respirometer (Gong et al., 2000) and methane oxidation assay (Seghers et al., 2003). Zabaloy et al., 2010 used BDOBS to assay mineralization of coumaric acid as an indication of PICT to 2,4-D in an agricultural and a forest soil. This study revealed that past field exposure of the agricultural soil to 2,4-D was enough to develop resistant microbial populations, while the herbicide exerted a more severe inhibitory effect on coumaric acid use in the pristine forest soil (Figure 9). In a similar study, Seghers et al. (2003) reported that long-term use of atrazine and metolachlor selected towards a methanotrophic community more tolerant to the methane oxidation inhibitor 2,4$\mathrm{D}$ in an agricultural soil.

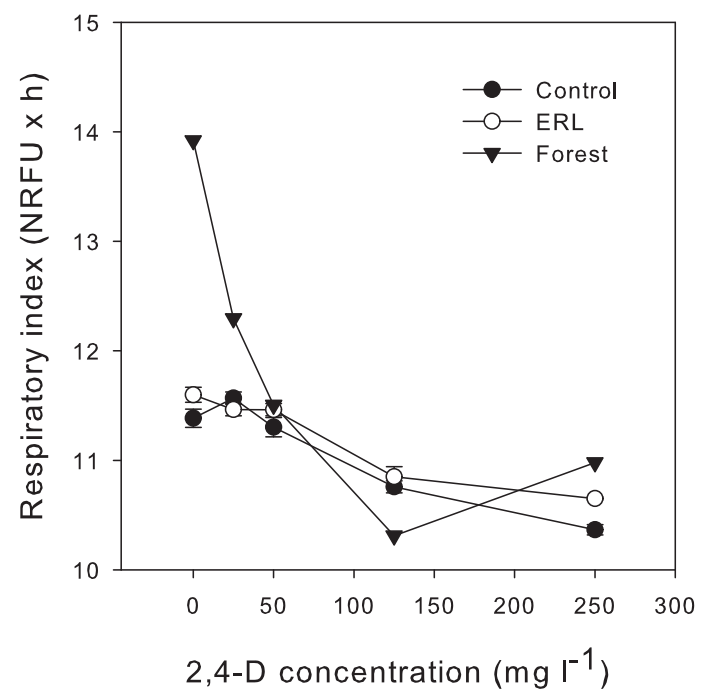

Fig. 9. Respiratory index with coumaric acid as $C$ source, in agricultural soil treated with 5 $\mathrm{mg} \mathrm{kg}^{-1}$ de 2,4-D (ERL) or untreated (control) and forest soil, exposed to increasing doses of 2,4-D (25-250 $\left.\mathrm{mg} \mathrm{l}^{-1}\right)$ in BDOBS. Values represent means \pm S.E $(n=3)$; for forest soil is the average of two samples. From Zabaloy et al., 2010

\section{Conclusion}

Although desorption has been considered a pre-requisite for biodegradation of soil-bound herbicides, there is increasing evidence that sorbed compounds may still be degraded by attached cells. However, there is still considerable work ahead for researchers to understand the mechanisms and populations intervening in these processes. Integrative approaches are essential to study physicochemical and biological factors that affect sorption, bioavailability and biodegradation of herbicides in soil. Development of new molecular methods coupling function and structure may improve our understanding of the role of microbial populations 
in herbicides degradation and how these compounds affect non-degrading members of the microbial community. Overall, a number of studies have shown that the herbicides 2,4-D, metsulfuron methyl and glyphosate at recommended rates have only transient impacts on soil microbial communities, being glyphosate the one with larger effects, while metsulfuron methyl may be toxic under certain soil conditions (e.g. high $\mathrm{pH}$ ).

\section{References}

Accinelli, C., Koskinen, W. C., Becker, J. M. \& Sadowsky, M. J. (2007). Environmental fate of two sulfonamide antimicrobial agents in soil, Journal of Agricultural and Food Chemistry 55: 2677-2682.

Accinelli, C., Screpanti, C., Dinelli, G. \& Vicari, A. (2002). Short-time effects of pure and formulated herbicides on soil microbial activity and biomass, International Journal of Environmental and Analytical Chemistry 82: 519-527.

Ainsworth, C. C., Frederickson, J. K. \& Smith, S. C. (1993). Effect of sorption on the degradation of aromatic acids and bases, in D. M. Linn, T. H. Carski, M. L. Brusseau \& F. H. Chang (eds), Sorption and Degradation of Pesticides and Organic Chemicals in Soil, Soil Science Society of America, Madison, WI, pp. 125-144.

Altieri, M. \& Pengue,W. (2006). GM soybean: Latin America's new coloniser, Seedling pp. 13- 17.

Andersen, S. M., Hertz, P. B., Holst, T., Bossi, R. \& Jacobsen, C. (2001). Mineralisation studies of ${ }^{14} \mathrm{CO}_{2}$-labeled metsulfuron-methyl, tibenuron-methyl, chlorsulfuron and thifensulfuron-methyl in one Danish soil and groundwater sediment profile, Chemosphere 45: 775-782.

Anderson, T.-H. (2003). Microbial eco-physiological indicators to assess soil quality, Agriculture, Ecosystems and Environment 98: 285-293.

Araújo, A. S. F., Monteiro, R. T. R.\&Abarkeli, R. B. (2003). Effect of glyphosate on the microbial activity of two Brazilian soils, Chemosphere 52: 799-804.

Avidano, L., Gamalero, E., Cossa, G. P. \& Carraro, E. (2005). Characterization of soil health in an Italian polluted site by using microorganisms as bioindicators, Applied Soil Ecology 30: 21-33.

Baelum, J., Henriksen, T., Hansen, H. C. B. \& Jacobsen, C. S. (2006). Degradation of 4-chloro2-methylphenoxyacetic acid in top- and subsoil is quantitatively linked to the class III tfdA gene, Applied and Environmental Microbiology 72: 1476-1486.

Baelum, J., Nicolaisen, M. H., Holben, W. E., Strobel, B. W., Sørensen, J., \& Jacobsen, C. S. (2008). Direct analysis of tfdA gene expression by indigenous bacteria in phenoxy acid amended agricultural soil, The ISME Journal 2: 677-687.

Beck, L., Römbke, J., Breure, A. M. \& Mulder, C. (2005). Considerations for the use of soil ecological classification and assessment concepts in soil protection, Ecotoxicology and Environmental Safety 62: 189-200.

Bedmar, F., Perdigón, J. A. \& Monterubbianesi, M. G. (2006). Residual phytotoxicity and persistence of chlorimuron and metsulfuron in soils of Argentina, Journal of Environmental Biology 27: 175-179. 
Benedetti, A. \& Dilly, O. (2006). Introduction, in J. Bloem, D. H. Hopkins \& A. Benedetti (eds), Microbiological Methods for Assessing Soil Quality, CABI Publishing, Wallingford, UK, pp. 3-14.

Benoit, P., Barriuso, E. \& Soulas, G. (1999). Degradation of 2,4-D, 2,4-dichlorophenol and 4chlorophenol in soil after sorption on humified and nonhumified organic matter, Journal of Environmental Quality 28: 1127-1135.

Berglöf, T., Koskinen, W. C., Duffy, M. C., Norberg, K. A. \& Kylin, H. (2003). Metsulfuron methyl sorption-desorption in field-moist soils, Journal of Agricultural and Food Chemistry 51: 3598-3603.

Blanck, H. (2002). A critical review of procedures and approaches used for assessing Pollution- Induced Community Tolerance (PICT) in biotic communities, Human and Ecological Risk Assessment 8: 1003-1034.

Blanck, H., Wängberg, S.-A. \& Molander, S. (1988). Pollution-induced community tolerancea new ecotoxicological tool, in J. J. Cairns \& J. R. Pratt (eds), Functional testing of aquatic biota for estimating hazards of chemicals, American Society for Testing and Materials, Philadelphia, PA, USA, pp. 219-230.

Blanco, M. \& Stoops, G. (1993). Genesis of pedons with discontinuous argillic horizons in the Holocene loess mantle of the southern Pampean landscape, Argentina, Journal of South American Earth Science 47: 353-359.

Boesten, J. J. T. I. (1993). Bioavailability of organic chemicals in soil related to their concentration in the liquid phase: a review, The Science Total Environment 134 Supplement 1: 397-407.

Bölter, M., Bloem, J., Meiners, K. \& Möller, R. (2006). Enumeration and biovolume determination of microbial cells, in J. Bloem, D. H. Hopkins \& A. Benedetti (eds), Microbiological Methods for Assessing Soil Quality, CABI Publishing, Wallingford, UK, pp. 93-107.

Borggaard, O. K. \& Gimsing, L. (2008). Fate of glyphosate in soil and the possibility of leaching to ground and surface waters: a review, Pest Management Science 64: 441456.

Boschin, G., Agostina, A., Arnoldi, A., Marotta, E., Zanardini, E., Negri, M., Valle, A. \& Sorlini, C. (2003). Biodegradation of chlorsulfuron and metsulfuron-methyl by Aspergillus niger in laboratory conditions, Journal of Environmental Science and Health. Part B 38: 737-746.

Brohon, B., Delolme, C. \& Gourdon, R. (2001). Complementarity of bioassays and microbial activity measurments for the evaluation of hydrocarbon-contaminated soils quality, Soil Biology and Biochemistry 33: 883-891.

Bunce, N. J. (1993). Introduction to Environmental Chemistry,Wuerz Publishing Ltd.,Winnipeg, Canada.

Burrows, L. A. \& Edwards, C. A. (2004). The use of integrated soil microcosms to assess the impact of carbendazim on soil ecosystems, Ecotoxicology 13: 143-161.

Busse, M. D., Ratcliff, A. W., Shestak, C. J. \& Powers, R. F. (2001). Glyphosate toxicity and the effects of long-term vegetation control on soil microbial communities, Soil Biology and Biochemistry 33: 1777-1789. 
Campbell, L. \& Davies, B. (1995). Soil sorption of cesium modeled by the Langmuir and Freundlich isotherm equations, Applied Geochemistry 10: 715-723.

Caspi, R., Altman, T., Dale, J. M., Dreher, K., Fulcher, C. A., Gilham, F., Kaipa, P., Karthikeyan, A. S. Kothari, A., Krummenacker, M., Latendresse, M., Mueller, L. A., Paley, S. M., Popescu, L., Pujar, A., Shearer, A., Zhang, P. \& Karp, P. (2010). The MetaCyc Database of metabolic pathways and enzymes and the BioCyc collection of pathway/Genome Databases, Nucleic Acids Research .

Cerdeira, A. L. \& Duke, S. O. (2006). The current status and environmental impacts of glyphosate-resistant crops: a review, Journal of Environmental Quality 35: 1633-1658.

Chander, K., Dyckmans, J., Hoeper, H., Joergensen, R. G. \& Raubuch, M. (2001). Long-term effects on soil microbial properties of heavy metals from industrial exhaust deposition, Journal of Plant Nutrition and Soil Science 164: 657-663.

Chen, H., He, X., Rong, X., Chen, W., Cai, P., Liang, W., Li, S. \& Huang, Q. (2009). Adsorption and biodegradation of carbaryl on montmorillonite, kaolinite and goethite, Applied Clay Science 46: 102-108.

Cheng, H. H. (1990). Pesticides in the Soil Environment: Processes, Impacts, and Modeling, Soil Science Society of America, Inc, Madison, Wisconsin, USA.

Chinalia, F. A. \& Killham, K. S. (2006). 2,4-Dichlorophenoxyacetic acid (2,4-D) biodegradation in river sediments of Northeast Scotland and its effect on the microbial communities (PLFA and DGGE), Chemosphere 64: 1675-1683.

Cooke, C., Shaw, G. \& Collins, C. D. (2004). Determination of solid-liquid partition coefficients $(\mathrm{kd})$ for the herbicides isoproturon and trifluralin in five UK agricultural soils, Environmental Pollution 132: 541-552.

Cramer, B. K., Westra, P. \& Zimdahl, R. L. (1993). Sorption, dissipation, and leaching of metsulfuron in Colorado soils, Weed Science 47: 353-359.

DiGiovanni, G. D., Neilson, J. W., Pepper, I. L. \& Sinclair, N. A. (1996). Gene transfer of Alcaligenes eutrophus JMP134 plasmid pJP4 to indigenous soil recipients, Applied and Environmental Microbiology 62: 2521-2526.

Dinelli, G., Vicari, A. \& Accinelli, C. (1998). Degradation and side effects of three sulfonylurea herbicides in soil, Journal of Environmental Quality 27: 1459-1464.

Dixon, J. B. \& Weed, S. B. (1990). Minerals in Soil Environments, Soil Science Society of America, Inc.

Don, R. H. \& Pemberton, J. M. (1981). Properties of six pesticide degradation plasmids isolated from Alcaligenes paradoxus and Alcaligenes eutrophus, Journal of Bacteriology 145: 681- 686.

Donnelly, P., Entry, J. \& Crawford, D. (1993). Degradation of atrazine and 2,4dichlorophenoxyacetic acid by mycorrhizal fungi at three nitrogen concentrations in vitro, Applied and Environmental Microbiology 59: 2642-2647.

Forlani, G., Mangiangalli, A., Nielsen, E. \& Suardi, C. M. (1999). Degradation of the phosphonate herbicide glyphosate in soil: evidence for a possible involvement of unculturable microorganisms, Soil Biology and Biochemistry 31: 991-997.

Frioni, L. (1981). Efecto de atrazina, linurón y 2,4-D amina sobre algunas propiedades biológicas de un suelo. II Ensayo de laboratorio, Revista Argentina de Microbiología pp. 9-16. 
Fukumori, F. \& Hausinger, R. P. (1993a). Alcaligenes eutrophus JMP134 "2,4dichlorophenoxyacetate monooxygenase" is an $\alpha$-ketoglutarate-dependent dioxygenase, Journal of Bacteriology 175: 2083-2086.

Fukumori, F. \& Hausinger, R. P. (1993b). Purification and characterization of 2,4dichlorophenoxyacetate/ $\alpha$-ketoglutarate dioxygenase, Journal of Biological Chemistry 32: 24311-24317.

Garland, J. L., Campbell, C. D. \& Mills, A. L. (2007). Physiological profiling of microbial populations, in C. J. Hurst, R. L. Crawford, J. L. Garland, D. A. Lipson, A. L. Mills \& L. D. Stezenbach (eds), Manual of Environmental Microbiology, 3 edn, ASM Press, Washington DC, USA, pp. 126-138.

Ghani, A. \&Wardle, D. (2001). Fate of ${ }^{14} \mathrm{C}$ from glucose and the herbicide metsulfuronmethyl in a plant-soil microcosm system, Soil Biology and Biochemistry 33: 777-785.

Gimsing, A. L., Borggaard, O. K., Jacobsen, O. S., Aamand, J. \& Sørensen, J. (2004). Chemical and microbiological soil characteristics controlling glyphosate mineralisation in Danish surface soils, Applied Soil Ecology 27: 233-242.

Gimsing, A., Szilas, C. \& Borggaard, O. (2007). Sorption of glyphosate and phosphate by variable-charge tropical soils from Tanzania, Geoderma 138: 127-132.

Gong, P., Gasparrini, P., Rho, D., Hawari, J., Thiboutot, S., Ampleman, G. \& Sunahara, G. I. (2000). An in Situ respirometric technique to measure pollution-induced microbial community tolerance in soils contaminated with 2,4,6-trinitrotoluene, Ecotoxicology and Environmental Safety 47: 96-103.

Greenland, D. \& Hayes, M. (1978). The Chemistry of Soil Constituents, JohnWiley Sons, London, Great Britain.

Gustafson, D. I. (1989). Groundwater ubiquity score: a simple method for assessing pesticide leachability, Environmental Toxicology and Chemistry 8: 339-357.

Hart, M. M., Powell, J. R., Gulden, R. H., Dunefield, K. E., Pauls, K. P., Swanton, C. J., Klironomos, J. N., Antunes, P. M., Koch, A. M. \& Trevors, J. T. (2009). Separating the effect of crop from herbicide on soil microbial communities in glyphosateresistant corn, Pedobiologia 52: 253-262.

Haws, N. W., Ball, W. P. \& Bouwer, E. J. (2006). Modeling and interpreting bioavailability of organic contaminant mixtures in subsurface environments, Journal of Contaminant Hydrology 82: 255-292.

Hay, J. V. (1990). Chemistry of sulfonylurea herbicides, Pesticide Science 29: 247-261.

He, Y., Shen, D., Hu, L. \& Zhu, Y. (2007). Study on metsulfuron-methyl degradation in simulated wheat (Triticum aestivum L.) rhizospheric soil with Penicillium sp. inoculation, Water, Air, and Soil Pollution, 179: 297-307.

Hermosín, M. C., Celis, R., Fanceda, G., Carrizosa, M., Ortega-Calvo, J. \& Cornejo, J. (2006). Bioavailability of the herbicide 2,4-D formulated with organoclays, Soil Biology and Biochemistry 38:2117-2124

Hinz, C. (2001). Description of sorption data with isotherm equations, Geoderma 99: 225-243.

Höper, H. (2006). Substrate-induced respiration, in J. Bloem, D. H. Hopkins \& A. Benedetti (eds), Microbiological Methods for Assessing Soil Quality, CABI Publishing, Wallingford, UK, pp. 84-92.

Hunter, R. (2002). Foundations of Colloid Science, Oxford University Press, Great Britain. 
Ismail, B. S., Yapp, K. F. \& Omar, O. (1998). Effects of metsulfuron-methyl on amylase, urease, and protease activities in two soils, Australian Journal of Soil Research 36: 449-456.

Joergensen, R. G. \& Emmerling, C. (2006). Methods for evaluating human impact on soil microorganisms based on their activity, biomass, and diversity in agricultural soils, Journal of Plant Nutrition and Soil Science 169: 295-309.

Johal, G. \& Huber, D. (2009). Glyphosate effects on diseases of plants, European Journal of Agronomy 31: 144-152.

Juhler, R. K., Henriksen, T. H., Ernestsen, V., Vinther, F. P. \& Rosenberg, P. (2008). Impact of basic soil parameters on pesticides disappearance investigated by multivariate partial least square regression and statistics, Journal of Environmental Quality 37: 1719-1732.

Ka, J. O., Burauel, P., Bronson, J. A., Holben, W. \& Tiedje, J. M. (1995). DNA probe analysis of microbial community selected in field by long-term 2,4-D-treated field soils, Soil Science Society of America Journal 59: 1581-1587.

Kah, J. M. \& Brown, C. D. (2006). Adsorption of ionisable pesticides in soils, Reviews of Environmental Contamination Toxicology 188: 149-217.

Kamagata, Y., Fulthorpe, R., Tamura, K., Takami, H., Forney, L. \& Tiedje, J. (1997). Pristine environments harbor a new group of oligotrophic 2,4- dichlorophenoxyacetic acid degrading bacteria, Applied and Environmental Microbiology 63(6): 2266-2272.

Ketelsen, H. \& Meyer-Windel, S. (1999). Adsorption of brilliant blue FCF by soils, Geoderma 90: 131-145.

Kibe, K., Takahashi, M., Kameya, T. \& Urano, K. (2000). Adsorption equilibriums of principal herbicides on paddy soils in Japan, The Science of the Total Environment 263: 115-125.

Kirk, J. L., Beaudette, L. A., Hart, M., Moutoglis, P., Klironomos, J. N., Lee, H. \& Trevors, J. T. (2004). Methods of studying soil microbial diversity, Journal of Microbiological Methods 58: 169-188.

Kishore, G. M. \& Jacob, G. S. (1987). Degradation of glyphosate by Pseudomonas sp. PG2982 via a sarcosine intermediate, Journal of Biological Chemistry 262: 12164-12168.

Kitagawa, W., Takami, S., Miyauchi, K., Masai, E., Kamagata, Y., Tiedje, J. M. \& Fukuda, M. (2002). Novel 2,4-dichlorophenoxyacetic acid degradation genes from oligotrophic Bradyrhizobium sp. strain HW13 isolated from a pristine environment, Journal of Bacteriology 184: 509-518.

Kononova, S. V. \& Nesmeyanova, M. A. (2002). Phosphonates and their degradation by microorganisms, Biochemistry (Moscow) 67(2): 184-195.

Kremer, R. \& Means, N. (2009). Glyphosate and glyphosate-resistant crop interactions with rhizosphere microorganisms, European Journal of Agronomy 31: 153-161.

Krzyśko-Lupicka, T. \& Orlik, A. (1997). The use of glyphosate as the sole source of phosphorus or carbon for the selection of soil-borne fungal strains capable to degrade this herbicide, Chemosphere 34: 2601-2605.

Krzysko-Lupicka, T. \& Sudol, T. (2008). Interactions between glyphosate and autochthonous soil fungi surviving in aqueous solution of glyphosate, Chemosphere 71: 1386-1391. 
Lancaster, S. H., Hollister, E. B., Senseman, S. A. \& Gentry, T. J. (2009). Effects of repeated glyphosate applications on soil microbial community composition and the mineralization of glyphosate, Pest Management Science 66: 59-64.

Langmuir, I. (1918). The adsorption of gases on plane surface of glass, mica and platinum, Journal of the American Chemical Society 40(9): 1361-1403.

Laor, Y., Strom, P.\&Farmer,W. J. (1996). The effect of sorption on phenanthrene bioavailability, Journal of Biotechnology 51: 227-234.

Lee, T., Kurata, S., Nakatsu, C. \& Kamagata, Y. (2005). Molecular analysis of bacterial community based on $16 \mathrm{~S}$ rDNA and functional genes in activated sludge enriched with 2,4-dichlorophenoxyacetic dcid (2,4-D) under different cultural conditions, Microbial Ecology 49.

Lerch, T., Dignac, M.-F., Barriuso, E., Bardoux, G. \& Mariotti, A. (2007). Tracing 2,4-D metabolism in Cupriavidus necator JMP134 with ${ }^{13} \mathrm{C}$-labelling technique and fatty acid profiling, Journal of Microbiological Methods 71: 162-174.

Lerch, T. Z., Dignac, M.-F., Nunan, N., Bardoux, G., Barriuso, E. \& Mariotti, A. (2009). Dynamics of soil microbial populations involved in 2,4-D biodegradation revealed by FAME-based Stable Isotope Probing, Soil Biology and Biochemistry 41: 77-85.

Lipok, J., Dombrovska, L., Wieczorek, P. \& Kafarski, P. (2003). The ability of fungi isolated from stored carrot seeds to degrade organophosphonate herbicides, Pesticide in Air, Plant, Soil and Water System, Proceedings of the XII Symposium Pesticide Chemistry.

Liu, C. M., McLean, P. A., Sookdeo, C. C. \& Cannon, F. C. (1991). Degradation of the herbicide glyphosate by memebers of the family Rhizobiaceae, Applied and Environmental Microbiology 57: 1799-1804.

Lupwayi, N. Z., Hanson, K. G., Harker, K. N., abd R. E. Blackshaw, G. W. C., O’Donovan, J. T., Johnson, E. N., Gan, Y., Irvine, R. B. \& Monreal, M. A. (2007). Soil microbial biomass, functional diversity and enzyme activity in glyphosate-resistant wheatcanola rotations under low-disturbance direct seeding and conventional tillage, Soil Biology and Biochemistry 39: 1418-1427.

Lynch, J. M., Benedetti, A., Insam, H., Nuti, M. P., Smalla, K., Torsvik, V. \& Nannipieri, P. (2004). Microbial diversity in soil: ecological theories, the contribution of molecular techniques and the impact of transgenic plants and transgenic microorganisms, Biology and Fertility of Soils 40: 363-385.

Macur, R. E., Wheeler, J. T., Burr, M. D. \& Inskeep, W. P. (2007). Impacts of 2,4-D application on soil microbial community and on populations associated with 2,4-D degradation, Microbiological Research 162: 37-45.

Martínez-Villegas, N., Flores-Vélez, L. M. \& Domínguez, O. (2004). Sorption of lead in soil as a function of pH: a study case in Mexico, Chemosphere 57: 1537-1542.

Martins, J. M. \& Mermoud, A. (1998). Sorption and degradation of four nitroaromatic herbicides in mono and multi-solute saturate/unsaturated soil batch sylstems, The Science of the Total Environment 33: 187-210.

McGowan, C., Fullthorpe, R. R.,Wrigth, A. M. \& Tiedje, J. M. (1998). Evidence for interspecies gene transfer in the evolution of 2,4-dichlorophenoxyacetic acid degraders, Applied and Environmental Microbiology 64: 4089-4092. 
McGrath, J. W., Ternan, N. G. \& Quinn, J. P. (1997). Utilization of organophosphonates by environmental microorganisms, Letters in Applied Microbiology 24: 69-73.

Merini, L. J., Cuadrado, V., Flocco, C. G. \& Giulietti, A. M. (2007). Dissipation of 2,4-D in soils of the Humid Pampa region, Argentina: a microcosm study, Chemosphere 68: 259-265.

Muller, R. H., Kleinsteuber, S. \& Babel, W. (2001). Physiological and genetic characteristics of two bacterial strains utilizing phenoxypropionate and phenoxyacetate herbicides, Microbiological Research 156: 121-131.

Nannipieri, P., Kandeler, E. \& Ruggiero, P. (2002). Enzyme activities and microbiological and biochemical processes in soil, in R. G. Burns \& R. P. Dick (eds), Enzymes in the Environment: Activity, Ecology and Applications, Marcel Dekker Inc., chapter 1, pp. 133.

Obojska, A., Ternan, N. G., Lejczak, B., Kafarski, P. \& McMullan, G. (2002). Organophosphonate utilization by the termophile Geobacillus caldoxylosilyticus T20, Applied and Environmental Microbiology 68: 2081-2084.

Ogram, A., Castro, H. \& Chauhan, A. (2007). Methods of soil microbial community analysis, in C. J. Hurst, R. L. Crawford, J. L. Garland, D. A. Lipson, A. L. Mills \& L. D. Stetzenbach (eds), Manual of Environmental Microbiology, 3 edn, ASM Press, Washington D.C., chapter 53, pp. 652-662.

Oliveira Jr., R. S., Koskinen, W. C. \& Ferreira, F. A. (2001). Sorption and leaching potential of herbicides on Brazilian soils, Weed Research 41: 97110.

Pallud, C., Dechesne, A., Gaudet, J. P., Debouzie, D. \& Grundmann, G. L. (2004). Modification of spatial distribution of 2,4-dichlorophenoyacetic acid degrader microhabitats during growth in soil columns, Applied and Environmental Microbiology 70: 2709-2716.

Pankhurst, C. E., Ophel-Keller, K., Doube, B. M. \& Gupta, V. V. S. R. (1996). Biodiversity of soil microbial communities in agricultural systems, Biodiversity Conservation 5: 197209.

Park, J.-H., Feng, Y., Ji, P., Voice, T. C. \& Boyd, S. A. (2003). Assessment of bioavailability of soil-sorbed atrazine, Applied and Environmental Microbiology 69: 3288-3298.

Park, J. H., Kay, D., Zhao, X. D., Boyd, S. A. \& Voice, T. C. (2001). Kinetic modelling of bioavailability for sorbed-phase 2,4-dichlorophenoxyacetic acid, Journal of Environmental Quality 30.

Parkin, T. B., Doran, J. W. \& Vizcaíno-Franco, E. (1996). Field and laboratory tests of soil respiration, in J. W. Doran \& A. J. Jones (eds), Methods for Assessing Soil Quality, no. 49 edn, ASA, CSSA, and SSSA, Madison, WI, pp. 231-245.

Pateiro-Moure, M., Pérez-Novo, C., Arias-Estévez, M., Rial-Otero, R. \& Simal-Gándara, J. (2009). Effect of organic matter and iron oxides on quaternary herbicide sorptiondesorption in vineyard-devoted soils, Journal of Colloid and Interface Science 333: 431438.

Pell, M. J., Stenström, J. \& Granhall, U. (2006). Soil respiration, in J. Bloem, D. H. Hopkins \& A. Benedetti (eds), Microbiological Methods for Assessing Soil Quality, CABI Publishing, Wallingford, UK, pp. 117-126. 
Pengue, W. A. (2004). Transgenic crops in Argentina and its hidden costs, in E. Ortega \& S. Ulgiati (eds), Proceedings of IV Biennial International Workshop Advances in Energy Studies, Campinas, Brazil, pp. 91-101.

Pimentel, D. (1995). Amounts of pesticides reaching target pests: Environmental impacts and ethics, Journal of Agricultural and Environmental Ethics 8: 17-29.

Piutti, S., Hallet, S., Rouseaux, S., Philippot, L., Soulas, G. \& Martin-Laurent, F. (2002). Accelerated mineralisation of atrazine in maize rhizosphere soil, Biology and Fertility of Soils 36: 434-441.

Pons, N. \& Barriuso, E. (1998). Fate of metsulfuron-methyl in soils in relation to pedoclimatic conditions, Pesticide Science 53: 311-323.

Powell, J. R., Levy-Booth, D. J., Gulden, R. H., Asbil, W. L., Campbell, R. G., Dunfield, K. E., Hamill, A. S., Hart, M. M., Lerat, S., Nurse, R. E., Pauls, K. P., Sikkema, P. H., Swanton, C. J., Trevors, J. T. \& Klironomos, J. N. (2009). Effects of genetically modified, herbicide-tolerant crops and their management on soil food web properties and crop litter decomposition, Journal of Applied Ecology 46: 388-396.

Preston-Mafham, J., Boddy, L. \& Randerson, P. F. (2002). Analysis of microbial community functional diversity using sole-carbon-source utilisation profiles: a critique, FEMS Microbiology Ecology. 42: 1-14.

Pusino, A., Pinna, V. \& Gessa, C. (2003). Azimsulfuron sorption-desorption on soil, Journal of Agricultural and Food Chemistry 52: 3462-3466.

Ratcliff, A.W., Busse, M. D. \& Shestak, C. J. (2006). Changes in microbial community structure following herbicide (glyphosate) additions to forest soils, Applied Soil Ecology 34: 114- 124.

Roberts, T. R. (ed.) (1998). Metabolic Pathways of Agrochemicals: Part 1. Herbicides and Plant Regulators, Royal Society of Chemistry.

Romero, M., Reinoso, E., Kiernan, A. M. \& Crdoba, S. (2004). Biodegradation of glyphosate by wild yeasts, Revista Mexicana de Micología 19: 45-50.

Sailaja, K. \& Satyaprasad, K. (2006). Degradation of glyphosate in soil and its effect on fungal population, Journal of Environmental Science and Engineering 48: 189-190.

Sannino, F. \& Gianfreda, L. (2001). Pesticides influence on soil enzymatic activities, Chemosphere 45: 417-425.

Schmitt, H., van Beelen, P., Tolls, J. \& Van Leeuwen, C. L. (2004). Pollution-induced community tolerance of soil microbial communities caused by the antibiotic sulfachloropyridazine, Environmental Science and Technology 38: 1148-1153.

Schnürer, Y., Persson, P., Nilsson, M., Nordgren, A. \& Giesler, R. (2006). Effects of sorption on microbial degradation of glyphosate, Environmental Science and Technology 40: 4145- 4150.

Seghers, D., Bulcke, R., Reheul, D., Siciliano, S., Top, E. \& Verstraete, W. (2003). Pollution induced community tolerance (PICT) and analysis of 16S rRNA genes to evaluate the long-term effects of herbicides on methanotrophic communities in soil, European Journal of Soil Science 54: 679-684.

Shaw, L. J. \& Burns, R. G. (2004). Enhanced mineralization of [U-14C]2,4dichlorophenoxyacetic acid in soil from the rhizosphere of Trifolium pratense, Applied and Environmental Microbiology 70(8): 4766-4774. 
Shaw, L. J. \& Burns, R. G. (2005). Rhizodeposits of Trifolium pratense and Lolium perenne: their comparative effects on 2,4-D mineralization in two contrasting soils, Soil Biology and Biochemistry 37: 995-1002.

Shaw, L. J. \& Burns, R. G. (2006). Enzyme activity profiles and soil quality, in J. Bloem, D. H. Hopkins \& A. Benedetti (eds), Microbiological Methods for Assessing Soil Quality, CABI Publishing, Wallingford, UK, pp. 158-171.

Siciliano, S. D. \& Roy, R. (1999). The role of soil microbial tests in ecological risk assessment: Differentiating between exposure and effects, Human and Ecological Risk Assessment 5: 671-682.

Singh, B. K. \& Walker, A. (2006). Microbial degradation of organophosphorous compounds, FEMS Microbiological Review 30: 428-471.

Smith, J. L. \& Collins, H. P. (2007). Management of organisms and their processes in soils, in E. A. Paul (ed.), Soil Microbiology, Ecology and Biochemistry, Academic Press, Oxford, UK, pp. 471-502.

Sørensen, S. R., Schulz, A., Jacobsen, O. S. \& Aamand, J. (2006). Sorption, desorption and mineralisation of the herbicides glyphosate and MCPA in samples from two Danish soil and subsurface profiles, Environmental Pollution 141: 184-194.

Sparks, D. (1986). Soil Physical Chemistry, CRC Press, Inc., Boca Raton, Florida, USA. Sparks, D. (2003). Environmental Soil Chemistry, Academic Press, California, USA.

Stenrød, M., Charnay, M.-P., Benoit, P. \& Eklo, O. M. (2006). Spatial variability of glyphosate mineralization and soil microbial characteristics in two Norwegian sandy loam soils as affected by surface topographical features, Soil Biology and Biochemistry 38: 962- 971.

Stumm, W. (1992). Chemistry of the Solid-Water Interface, John Wiley Sons, Inc., New York, USA.

Tiedje, J. M., Duxbury, J. M., Alexander, M. \& Dawson, J. E. (1969). 2,4-D metabolism: pathway of degradation of chlorocatechols by Arthrobacter sp., Journal of Agricultural and Food Chemistry 17: 1021-1026.

Torsvik, V., Sørheim, R. \& Goksøyr, J. (1996). Total bacterial diversity in soil and sediment communities a review, Journal of Industrial Microbiology. 17: 170-178.

Vallaeys, T., Fullthorpe, R. R., Wrigth, A. M. \& Soulas, G. (1996). The metabolic pathway of 2,4-dichlorophenoxyacetic acid degradation involves different families of $t f d A$ and $t f d B$ genes according to PCR-RFLP analysis, FEMS Microbiology Ecology. 20: 163-172.

Valverde-García, A., Gonzalez-Pradas, E., Villafranca-Sanchez, M., Rey-Bueno, F. D. \& García- Rodriguez, A. (1998). Adsorption of tirad and dimethoate on Almeria soils, Soil Science Society American Journal 52: 1571-1574.

van Eerd, L. L., Hoagland, R. E., Zablotowicz, R. M. \& Hall, J. C. (2003). Pesticide metabolism in plants and microorganisms, Weed Science 51: 472-495.

Vázquez, B., Curvetto, N. \& Bianchinotti, M. (2008). Hongos degradadores de metsulfurón metilo presentes en suelos agrícolas de Argentina. Aislamiento y evaluación, Proceedings of VI CLAM Congreso Latinoamericano de Micología, p. 308.

Vázquez, M., Bianchinotti, M. \& Curvetto, N. (2009). Resistencia de aislamientos de Trichoderma harzianum a altas concentraciones de metsulfurón metilo, Boletín de la Sociedad Argentina de Botánica, Vol. 44 (Supl.), pp. 130-131. 
Vieublé-Gonod, L., Chadoeuf, J. \& Chenu, C. (2005). Spatial distribution of microbial 2,4dichlorophenoxy acetic acid mineralization from field to microhabitat scales, Soil Science Society of America Journal 70(1): 64-71.

Vieublé-Gonod, L., Martin-Laurent, F. \& Chenu, C. (2006). 2,4-D impact on bacterial communities, and the activity and genetic potential of 2,4-D degrading communities in soil, FEMS Microbiology Ecology 58: 529-537.

Vroumsia, T., Steiman, R., Seigle-Murandi, F., Benoit-Guyod, J. \& Groupe pour l'Étude du Devenir des Xénobiotiques dans l'Environnement (GEDEXE), G. (2005). Fungal bioconversion of 2,4-dichlorophenoxyacetic acid (2,4-D) and 2,4-dichlorophenol (2,4-DCP), Chemosphere 60: 1471-1480.

Walker, A., Cotterill, E. G. \& Welch, S. J. (1989). Adsorption and degradation of chlorsulfuron and metsulfuron-methyl in soils from different depths, Weed Research 29: 28-37.

Wardle, D. A. \& Parkinson, D. (1990). Effects of three herbicides on soil microbial activity and biomass, Plant and Soil 122: 21-28.

Weaver, M. A., Krutz, L. J., Zablotowicz, R. M. \& Reddy, K. N. (2007). Effects of glyphosate on soil microbial communities and its mineralization in a Mississippi soil, Pest Management Science 63: 388-393.

Weber, J. B., Wilkerson, G. G. \& Reinhardt, C. F. (2002). Calculating pesticide sorption coefficients $\left(\mathrm{K}_{\mathrm{d}}\right)$ using selected soil properties, Chemosphere 55: 157-166.

Woodburn, A. T. (2000). Glyphosate: production, pricing, and use worldwide, Pest Management Science 56: 309-312.

Xi, Y., Mallavarapu, M. \& Naidu, R. (2010). Adsorption of the herbicide 2,4-D on organopalygorskite, Applied Clay Science 49: 255-261.

Yao, X., Min, H., Lü, Z. \& Yuan, H. (2006). Influence of acetamiprid on soil enzymatic activities and respiration, European Journal Soil Biology 42: 120-126.

Yu, Y., Wang, X., Luo, Y., Yang, J., Yu, J. \& Fan, D. (2005). Fungal degradation of metsulfuron methyl in pure cultures and soil, Chemosphere 60: 440-466.

Zabaloy, M. C., Garland, J. L. \& Gómez, M. A. (2008). An integrated approach to evaluate the impacts of the herbicides glyphosate, 2,4-D and metsulfuron-methyl on soil microbial communities in the Pampas region, Argentina, Applied Soil Ecology 40: 112.

Zabaloy, M. C., Garland, J. L. \& Gómez, M. A. (2009). Assessment of microbial community function and structure in soil microcosms exposed to glyphosate, Proceedings of the VI Congress of the Argentine Society of General Microbiology- SAMIGE, Carlos Paz, Argentina, p. 40. URL: www.samige.org.ar/2009.php

Zabaloy, M. C., Garland, J. L. \& Gómez, M. A. (2010). Assessment of the impact of 2,4dichlorophenoxyacetic acid (2,4-D) on indigenous herbicide-degrading bacteria and microbial community function in an agricultural soil, Applied Soil Ecology 46: 240246.

Zabaloy, M. C. \& Gómez, M. A. (2008). Microbial respiration in soils of the Argentine Pampas after metsulfuron-methyl, 2,4-D and glyphosate treatments, Communications in Soil Science and Plant Analysis 39: 370-385. 
Zanardini, E., Arnoldi, A., Boschin, G., Agostina, A., Negri, M. \& Sorlini, C. (2002). Degradation pathways of chlorsulfuron and metsulfuron-methyl by a Pseudomonas fluorescens strain, Annals of Microbiology 52: 25-37.

Zanini, G., Avena, M., Fiol, S. \& Arce, F. (2006). Effects of pH and electrolyte concentration on the binding between a humic acid and an oxazine dye, Chemosphere 63: 430-439.

Zanini, G. P., Maneiro, C., Waiman, C., Galantini, J. A. \& Rossel, R. A. (2009). Adsorption of metsulfuron methyl on soils under no-till system in semiarid Pampean Region, Argentina, Geoderma 149: 110-115. 


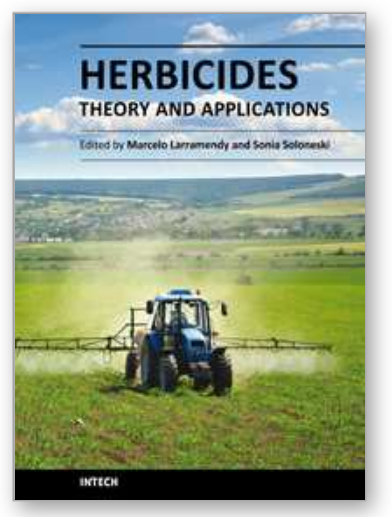

\author{
Herbicides, Theory and Applications \\ Edited by Prof. Marcelo Larramendy
}

ISBN 978-953-307-975-2

Hard cover, 610 pages

Publisher InTech

Published online 08, January, 2011

Published in print edition January, 2011

The content selected in Herbicides, Theory and Applications is intended to provide researchers, producers and consumers of herbicides an overview of the latest scientific achievements. Although we are dealing with many diverse and different topics, we have tried to compile this "raw material" into three major sections in search of clarity and order - Weed Control and Crop Management, Analytical Techniques of Herbicide Detection and Herbicide Toxicity and Further Applications. The editors hope that this book will continue to meet the expectations and needs of all interested in the methodology of use of herbicides, weed control as well as problems related to its use, abuse and misuse.

\title{
How to reference
}

In order to correctly reference this scholarly work, feel free to copy and paste the following:

M. Celina Zabaloy, Graciela P. Zanini, Virginia Bianchinotti, Marisa A. Gomez and Jay L. Garland (2011). Herbicides in the Soil Environment: Linkage between Bioavailability and Microbial Ecology, Herbicides, Theory and Applications, Prof. Marcelo Larramendy (Ed.), ISBN: 978-953-307-975-2, InTech, Available from: http://www.intechopen.com/books/herbicides-theory-and-applications/herbicides-in-the-soil-environmentlinkage-between-bioavailability-and-microbial-ecology

\section{INTECH}

open science | open minds

\author{
InTech Europe \\ University Campus STeP Ri \\ Slavka Krautzeka 83/A \\ 51000 Rijeka, Croatia \\ Phone: +385 (51) 770447 \\ Fax: +385 (51) 686166 \\ www.intechopen.com
}

\author{
InTech China \\ Unit 405, Office Block, Hotel Equatorial Shanghai \\ No.65, Yan An Road (West), Shanghai, 200040, China \\ 中国上海市延安西路65号上海国际贵都大饭店办公楼 405 单元 \\ Phone: +86-21-62489820 \\ Fax: $+86-21-62489821$
}


(C) 2011 The Author(s). Licensee IntechOpen. This chapter is distributed under the terms of the Creative Commons Attribution-NonCommercialShareAlike-3.0 License, which permits use, distribution and reproduction for non-commercial purposes, provided the original is properly cited and derivative works building on this content are distributed under the same license. 